The Journal of Animal \& Plant Sciences, 30(4): 2020, Page: 970-987

ISSN (print): 1018-7081; ISSN (online): 2309-8694

\title{
LONG-TERM APPLICATION EFFECTS OF ORGANIC AND CHEMICAL FERTILIZERS ON SOIL HEALTH AND PRODUCTIVITY OF TARAMIRA (ERUCA SATIVA L.) UNDER RAINFED CONDITIONS
}

\author{
R. S. Noor ${ }^{1,2}$, Z. Wang ${ }^{1}$, M. Umair ${ }^{2}$, M. Ameen ${ }^{3}$, M. A. Misaal ${ }^{2}$ and Y. Sun ${ }^{1 *}$ \\ ${ }^{1}$ Department of Agricultural, Biological, Environment and Energy Engineering, College of Engineering, Northeast \\ Agricultural University, Harbin 150030, China \\ ${ }^{2}$ Faculty of Agricultural Engineering \& Technology, PMAS-Arid Agriculture University, Rawalpindi 46000, Pakistan \\ ${ }^{3}$ College of Engineering, Nanjing Agricultural University, Nanjing 210031, China \\ "Correspondence author's e-mail: sunyong@neau.edu.cn
}

\begin{abstract}
Intensive cultivation system suffers from production fatigue caused by declining soil organic matter, multi-nutrient deficiencies and diminishing factor productivity. A long term field experiment (2015-16 to 2018-19) was conducted to determine the impact of sole and integrated application of farm yard manure (FYM) and Chemical fertilizer (RDF); sole organic fertilizer (OF), chemical fertilizers (RDF) and potassium phosphate (RPK) while half dose of chemical fertilizer with full and half dose of organic fertilizer (HDF+OF and HDF+HOF) as well as the RPK with nitrogen foliar $(\mathrm{RPK}+\mathrm{NF})$ as integrated fertilizer options and controlled (CK) on soil properties, plant growth characteristics and crop productivity in completely randomized design (CRD). The long-term fertilizer results revealed that the organic and integrated fertilizer options significantly enhanced plant growth characteristics, yield and seed quality. The yield trends were positive $(\mathrm{p} \leq 0.05)$ under all organic fertilizers but, integrated fertilizer $(\mathrm{HDF}+\mathrm{OF})$ significantly increased plant height, branches/plant, root length, disease resistance, siliqua/plant, siliqua length, seeds/siliqua, 1000 seed weight, and seed yield. The annual seed yield obtained from the field fertilized with (HDF+OF) were 10,12, 18 and 22\% more than that of the field fertilized with chemical fertilizer, respectively during four years of study. Oil, protein, glucosinolates and acids contents in seed also increased with organic fertilizer. Eruca plant leaves fertilized with (HDF+OF) contained higher bioactive substance concentrations as L-ascorbic acid $\left(119.36 \pm 0.48 \mathrm{mg} 100 \mathrm{~g}^{-1} \mathrm{FM}\right)$, chlorophyll $(0.73 \pm 0.01 \mathrm{mg}$

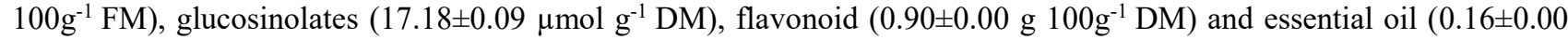
$\left.\mathrm{ml} 100 \mathrm{~g}^{-1} \mathrm{DM}\right)$. Integrated fertilizers proved to be more beneficial due to improved nutritional contents and energy values in eruca sativa leaves. The senescence was effectively delayed throughout the storage period of 0 and $5^{\circ} \mathrm{C}$. Compared with chemical fertilizers, the organic fertilizers significantly improved bulk density and soil chemical health (SOC, $\mathrm{NO}_{3}-\mathrm{N}, \mathrm{NH}_{4}-\mathrm{N}, \mathrm{P}, \mathrm{K}, \mathrm{S}, \mathrm{Zn}$ contents).
\end{abstract}

Keywords: Eruca sativa L., fertilizer options, plant development, seed yield \& quality, bioactive substance \& nutritional values, leave storage performance and soil chemical health.

https://doi.org/10.36899/JAPS.2020.4.0113

Published online April 25, 2020

\section{INTRODUCTION}

Agricultural lands show multi-dimensional variability in physiochemical characteristics of soil and managerial practices of ecosystems, which influences the composition and activity in soil strata (Bowles et al., 2014). Soil is the composite medium for mutual collaboration of plants and microorganisms to extract nutrients and water. The organic matter is mainly dependent on microbial biomass which is responsible for maintaining soil fertility and quality (Yao et al., 2000). Higher the amount of soil organic matter (SOM), the more supply of nutrient which improves the soil's biological and physical characteristics. Therefore, maintaining the SOM plays a vital role in enhancing the productivity of ecosystems. Some of the prominent methods like fertilization improve significantly the SOM. The estimation of SOM is mostly done through soil organic content (SOC) and changes in SOC, which effects the $\mathrm{N}$ and $\mathrm{C}$ cycle in the global ecosystem (Malhi et al., 2011). The variation in Carbon and Nitrogen cycles are the results of the interactive effects of biological and chemical characteristics of soil (Zhao et al., 2016).

The soils of Pakistan are deficient in major and minor nutrients. The most important factor is Nitrogen (N) which influences the crop productivity and quality. Only a small portion of the nitrogen is biologically active, acting as Nitrogen fixation. The fertilizers were applied to the crops for better yield through improved nutrition and carbon to nitrogen content is an important and old agricultural practice, which has been resulted in changing variety and activities of soil microorganisms (Ding et al., 2016). It was observed that a greater amount of $\mathrm{K}$ 
available in soil improves the intake of carbohydrate mechanism in plants and acts as a key nutrient for optimum crop yield. Potassium and Phosphorus are important nutrients which result in a significant portion of fertilizers application expenditures (Fan et al., 2012). Since Nitrogen is an integral part of plant structure, optimum content of nitrogen must be present for proper development of the plant. The plant uptake nitrogen in the form of anion $\mathrm{NO}_{3}{ }^{-}$and $\mathrm{NH}_{4}{ }^{+}$(Wierdak, 2009). The balanced fertilizer application increases the crop yield up to $50 \%$. However, Improper and excessive application of fertilizers is harmful to the ecosystem, affects the crop yields and meeting the growing demand and sustainable agriculture (Singh et al., 2019).

The increasing use of NPK fertilizers has enhanced food production but the extensive use of chemical fertilizers has negative effects on sustainable agriculture while, the organic production system aims at supporting and sustaining healthy ecosystems, soil, farmers, food production, the community, and the economy. Reduction and elimination of the adverse effects of synthetic fertilizers and pesticides on human health and the environment is a strong indicator that organic agriculture is gaining worldwide attention. Farmyard manure, municipal zero waste, and green manure are the principle sources of organic matter and has been used a long ago to increase soil fertility and plant nutrition. Organic fertilizers are environmentally friendly since they are from organic sources (Oyewole et al., 2012). The current global scenario firmly emphasizes the need to adopt eco-friendly agricultural practices for sustainable food production. In addition to quality improvement, soil structure is also improved (Thomas et al., 1996).

The organic fertilizers provide nutritional requirements, suppress plant pest populations, and increase the yield and quality of agricultural crops in ways like inorganic fertilizers (Liu et al., 2007). Ould et al., (2010), stated that the improvement in physical and biological properties of plants and soil was observed by incorporation of organic manure. Solaiman and Rabbani (2006), reported results and their findings on the application of a combination of cow dung and a half dose of inorganic fertilizer on leafy crops. Biofertilizers such as Trichoderma enriched with inorganic fertilizers play a significant role in the growth and yield of crops and have the potential to reduce $50 \%$ of the cost of inorganic fertilizers. Organic fertilizers contain macro-nutrients, essential micro-nutrients, vitamins, growth-promoting indole acetic acid (IAA), gibberellic acid (GA) and beneficial microorganisms (Sreenivasa et al., 2010).

Taramira (Eruca sativa L.) from brassica family is known as "Rocket salad", also called garden salad which is an important non-edible oilseed crop among mustard and rapeseed group (Padulosi et al., 2002). It is cultivated as leaf vegetable or in cultivated form for oilseeds (Henalt et al., 2013) under different soil and climatic conditions of irrigated and rainfed areas of Pakistan under temperature ranges $10-25^{\circ} \mathrm{C}$ (Dolezalova et al., 2013).

The goal of our study was to evaluate the influence of long-term application of inorganic fertilizer (NPK), organic fertilizer (farmyard manure, FYM), and their combination (NPK+FYM) on soil chemical health, crop development characteristics, crop yield, oil contents, and nutritional contents both in leaf and seed oil. The quality deteriorates of Eruca sativa during post-harvest, in relation to time and storage temperatures at 0,5 and $10^{\circ} \mathrm{C}$ for over 15 days were also examined.

\section{MATERIALS AND METHODS}

This research study was conducted consecutively during four cropping winter (Rabi) seasons 2015-16 to 2018-19 at Research Farm Koont, PMAS Arid Agriculture University, Rawalpindi to investigate the effects of various fertilization options comprising of organic and inorganic fertilizers on soil chemical health, plant vegetative growth \& development, crop yield, seed quality, bioactive substances, nutritional \& energetic values in leaf of taramira (Eruca Sativa L.) crop. The post-harvest storage performance as physiological and visual quality was also identified under storage temperatures $\left(0,5\right.$ and $\left.10^{\circ} \mathrm{C}\right)$ for 15 days. Soil of the experimental site was sandy loam in texture ( $15.63 \pm 0.01 \%$ clay, $16.72 \pm 0.30 \%$ silt and $66.93 \pm 0.63 \%$ sand) and the other physio-chemical properties within the soil profile $0-60 \mathrm{~cm}$ at the commencement (2015-16) of long-term application of different fertilizers were determined and presented in Table 3. Research farm Koont is in the Eastern part of Pothwar plateau represents as mechanized rainfed cultivation system. The experimental site was sub-tropical with hot dry summers and cold winters. The average rainfall, maximum and minimum temperature during the crop period (NovemberMarch) during all cropping seasons were recorded. Apparently, no remarkable changes were found in the weather parameters over the experimentation time. The average monthly minimum and maximum temperatures fluctuated from $9-15^{\circ} \mathrm{C}$ and $20-27^{\circ} \mathrm{C}$.

The field under experiment was ploughed conventionally during entire period. The field experiment consisted of seven treatments comprising of organic and inorganic fertilizers consisting of Control or no-fertilizer (CK), NPK recommended (RDF), FYM recommended (OF), $1 / 2$ Chemical NPK + FYM recommended $(\mathrm{HDF}+\mathrm{OF}), 1 / 2$ Chemical NPK + 1/2 FYM recommended (HDF+HOF), Only PK recommended (RPK), PK Recommended $+\mathrm{N}$ Foliar Application $(\mathrm{RPK}+\mathrm{NF})$. The quantity of fertilizer applied under each fertilizer strategies are presented in Table 1 . The experiment was laid out under completely randomized design (CRD) with three replications. 
Table 1. Fertilizer strategies, description and their doses.

\begin{tabular}{ccc}
\hline Fertilizer strategies & Description & Dose (kg/ha) \\
\hline CK & Control & No Fertilizer Applied- \\
RDF & NPK Chemical Recommended & NPK $30 \mathrm{~kg}$ each) \\
OF & FYM Recommended & 17.2 tones \\
HDF + OF & $1 / 2$ Chemical + FYM Recommended & $15 \mathrm{~kg}$ each +17.2 tones \\
HDF + HOF & $1 / 2$ Chemical + 1/2 FYM Recommended & $15 \mathrm{~kg} \mathrm{each}+8.6$ tones \\
RPK & Only PK Chemical Recommended & $30 \mathrm{~kg}$ each \\
RPK $+\mathrm{NF}$ & Chemical Recommended PK+ N, Foliar Application & $30 \mathrm{~kg}$ each $+2-3 \mathrm{~kg}$ \\
\hline
\end{tabular}

The total area of experimental field was $10,500 \mathrm{~m}^{2}$ which was divided into total 21 plots for seven treatments with three replications. Experimental field area was prepared by conventional method and the area of each subplot was $500 \mathrm{~m}^{2}(25 \mathrm{~m} \times 20 \mathrm{~m})$. The recommended NPK rates $\left(120 \mathrm{~kg} \mathrm{ha}^{-1} \mathrm{~N}, 30 \mathrm{~kg} \mathrm{ha}^{-1} \mathrm{P}\right.$ and $\left.33 \mathrm{~kg} \mathrm{ha}^{-1} \mathrm{~K}\right)$ were applied in form of Urea $(46 \% \mathrm{~N})$, diammonium phosphate (DAP, $18 \% \mathrm{~N}$ and $20 \% \mathrm{P}$ ) and potash $(\mathrm{MOP}, 50 \% \mathrm{~K})$ respectively. The FYM was incorporated into the soil of OF treatment plots one week before crop sowing. The quantity of farmyard manure (FYM) applied was estimated based on the mineral contents. The average percentage composition of FYM was C $29.4 \pm 3.1, \mathrm{~N} 0.69 \pm 0.04, \mathrm{P} 0.27 \pm 0.02$, K $0.54 \pm 0.03$,
S $0.18 \pm 0.06$ and $\mathrm{C}: \mathrm{N}$ ratio of 6.2 . Thus, the quantity of FYM applied annually in $\mathrm{OF}, \mathrm{HDF}+\mathrm{OF}$ and $\mathrm{HDF}+\mathrm{HOF}$ treatments were $17.2 \mathrm{t} \mathrm{ha}^{-1}, 17.2 \mathrm{t} \mathrm{ha}^{-1}$ and $8.6 \mathrm{t} \mathrm{ha}^{-1}$ respectively.

The E. Vesicaria variety of taramira crop was selected (Syngenta seed, Pakistan) and sown during all cropping seasons. Each year the crop was sown during the first week of November under rainfed irrigation conditions as shown in Table 2. The chemical herbicides were also used to remove weeds from all treatment plots except OF treatment plot wherein the weeds were managed through manual weeding. The crop was harvested manually at the full maturity stage in March.

Table 2. Sowing-harvesting dates and duration of crop periods from 2015-16 to 2018-19.

\begin{tabular}{cccc}
\hline Sowing date & Harvesting date & Crop period (days) & Total rainfall (mm) \\
\hline 01 November 2015 & 05 March 2016 & 126 & 25.29 \\
05 November 2016 & 09 March 2017 & 125 & 64.80 \\
03 November 2017 & 17 March 2018 & 134 & 32.44 \\
01 November 2018 & 11 March 2019 & 131 & 224 \\
\hline
\end{tabular}

The characteristics regarding soil physical health, plant growth characteristics, yield and seed quality, Biological active substance, nutritional content and energetic value of plant leaves and quality deteriorates during storage were studied to identify the most efficient fertilization option(s) and storage conditions.

Soil chemical health: The soil physical health was determined both at commencement of experiment and after harvesting of each season. The soil samples from three different locations in each plot were collected within soil profile depth $0-60 \mathrm{~cm}$ at $15 \mathrm{~cm}$ depth interval both before and after the crop sowing. A core sampler of $8 \mathrm{~cm}$ diameter was used to collect soil samples. The collected samples were pulverized and sieved through a 2 $\mathrm{mm}$ sieve before determining the soil physical properties. The soil physical parameters like bulk density of soil samples were measured at soil profile 0-15, 15-30, 30-45 and $45-60 \mathrm{~cm}$ depths using undisturbed soil cores (Blake and Hartge, 1986) before commencement of study 2015-
16 and in the terminal year. The gravimetric method was used after oven drying for $48 \mathrm{~h}$ at $105^{\circ} \mathrm{C}$. The electric conductivity using EC meter, $\mathrm{pH}$ (1:2.5 Soil water suspensions) (Page et al., 1992) were also determined.

The processed samples were analyzed for mineral N content (Bremner and Keeney, 1965) and organic carbon (Walkley and Black, 1934) at all soil profile depth. The available phosphorous content $(0.5 \mathrm{M}$ $\mathrm{NaHCO}_{3}$, pH 8.5 extractable) (Olsen et al., 1954), potassium content (1 $\mathrm{M} \mathrm{NH} \mathrm{NH}_{4} \mathrm{OAc}, \mathrm{pH} 7.0$ extract), available Sulphur content $\left(0.15 \% \mathrm{CaCl}_{2}\right.$ extraction) and available zinc (DTPA-CaCl2-TEA, pH 7.3 extraction) (Lindsay and Norvell 1978), were calculated. Soil characteristics in surface soil layer $(0-15 \mathrm{~cm}$ depth) measured at the commencement of experiment in 201516 showed that the soil was mildly alkaline $(\mathrm{pH} \mathrm{8.17)} \mathrm{and}$ non-saline (EC) $0.93 \pm 0.05 \mathrm{dSm}^{-1}$, contained $5.5 \mathrm{~g} \mathrm{~kg}^{-1}$ SOC, $8.8 \pm 0.07 \mathrm{~g} \mathrm{~kg}^{-1} \mathrm{P}, 76.2 \pm 1.22 \mathrm{gkg}^{-1} \mathrm{~K}, 14.7 \pm 1.22 \mathrm{~g}$ $\mathrm{kg}^{-1} \mathrm{~S}$ and $0.6 \pm 0.07 \mathrm{~g} \mathrm{~kg}^{-1}$ DTPA-Zn contents. 
Growth, yield and seed quality: Manual harvesting was carried out when the color of siliqua had turned to brown, before siliqua cracking. The plants were dried under shade and threshed manually. To plant vegetative growth characteristics including plant height $(\mathrm{cm})$, root length (cm) and branches per plant, 20 plants were selected randomly while length of siliqua and number of seeds per siliqua were determined on 30 randomly selected siliqua for each treatment. Seed yield per hectare $(\mathrm{kg} / \mathrm{ha})$ was estimated using plot seed yield. Thousand seed weight was carried out under ISTA, 1996 rules.

Table 3. Physio-chemical properties of soil prior to long term fertilizer application strategies.

\begin{tabular}{|c|c|c|c|c|c|c|c|c|c|c|}
\hline \multirow{2}{*}{$\begin{array}{c}\text { Soil } \\
\text { depth } \\
(\mathrm{cm})\end{array}$} & \multirow{2}{*}{$\begin{array}{c}\text { Bulk } \\
\text { density } \\
(\mathrm{Mgm-3})\end{array}$} & \multirow{2}{*}{$\begin{array}{c}\text { EC } \\
(d s / m)\end{array}$} & \multirow[b]{2}{*}{$\mathbf{p H}$} & \multirow{2}{*}{$\begin{array}{c}\text { Organic } \\
\text { carbon } \\
\left(\mathrm{g} \mathrm{kg}^{-1}\right)\end{array}$} & \multicolumn{6}{|c|}{ Available (mg kg $\left.{ }^{-1}\right)$} \\
\hline & & & & & NO3-N & NH4-N & $\mathbf{P}$ & $\mathbf{K}$ & $\mathbf{S}$ & $\begin{array}{c}\text { DTPA- } \\
\text { Zn }\end{array}$ \\
\hline $0-15$ & $1.5 \pm 0.07$ & $0.93 \pm 0.05$ & $8.17 \pm 0.04$ & $5.5 \pm 0.14$ & $7.1 \pm 0.18$ & $11.5 \pm 0.04$ & $8.8 \pm 0.07$ & $76.2 \pm 1.22$ & $14.7 \pm 1.22$ & $0.6 \pm 0.07$ \\
\hline $15-30$ & $1.53 \pm 0.05$ & $0.96 \pm 0.06$ & $8.06 \pm 0.03$ & $4.2 \pm 0.17$ & $6.7 \pm 0.14$ & $11.7 \pm 0.04$ & $6.5 \pm 0.06$ & $67.6 \pm 2.38$ & $9.8 \pm 0.35$ & $0.48 \pm 0.05$ \\
\hline $30-45$ & $1.59 \pm 0.08$ & $1.1 \pm 0.05$ & $7.88 \pm 0.05$ & $3.7 \pm 0.11$ & $6.3 \pm 0.11$ & $11.6 \pm 0.05$ & $5.2 \pm 0.17$ & $60.3 \pm 1.8$ & $8.7 \pm 0.18$ & $0.42 \pm 0.06$ \\
\hline $45-60$ & $1.62 \pm 0.04$ & $1.13 \pm 0.04$ & $7.71 \pm 0.05$ & $2.2 \pm 0.07$ & $5.5 \pm 0.09$ & $10.8 \pm 0.06$ & $4.9 \pm 0.06$ & $57.7 \pm 1.9$ & $6.4 \pm 0.06$ & $0.38 \pm 0.04$ \\
\hline
\end{tabular}

The plant survival against powdery mildew disease was determined by evaluating disease index. Podosphaera xanthii (castaggne) also called sphaerotheca fuliginea was used as powdery mildew. The inoculum was prepared and sprayed onto the first, seventh and 15th leaves with conidial suspension $(105 / \mathrm{ml})$ and incubated as discussed by. For the first test at first true leaf, the cotyledon taken from all four rootstocks cultivars were inoculated and incubated at $20-26^{\circ} \mathrm{C}$ because resistive reaction is temperature dependent (Morishita et al., 2002). The second and third tests were performed at seventh and fifteenth leaf stage with three replications after four weeks of germination.

The measurement was taken of parameters like crop yield $(\mathrm{kg} / \mathrm{ha})$, seed number per pod, number of seeds per plant, total seeds per pod, oil content $(\%)$, protein content $(\%)$, glucosinolates content $(\%)$, oleic acid $(\%)$, Linolic acid (\%) and Euric acid (\%) by different instruments at research farm. The oil quality and nutrient content were calculated by Near Infrared Reflectance Spectroscopy (NIRS) (Sato et al., 2008).

Bioactive substance, nutritional and energetic values in eruca leaves: The plant leaves were harvested after 55-60 days from sowing to determine bioactive substance nutritional values and energetic contents in rocket plant leaves. The leaf fresh matter and biological substance including L-ascorbic acid (fresh leaves), chlorophyll, flavonoids, glucosinolates and essential oil (dried leaves at temperature $35^{\circ} \mathrm{C}$ ). The proximate compositions (moisture, fibre, ash and fats) of the samples were determined using methods described by (Pearson, 1976). The moisture and ash were determined using weight difference methods. Proteins were determined by the Kjeldahl method, described by (AOAC, 1990). The gross energy content of the different samples was computed from the proximate constituents by WEENDE method (accordingly energy value of the nutritional compounds) as described by (AOAC, 1980). Soluble sugar content of eruca sativa leaves were determined by HPLC method. The soluble sugars contents to be determined were separated on a chromatographic column filled with cation exchange resin (sulfonated polystyrene-divinylbenzene copolymer as $\mathrm{Ca}^{2+}$ ). The mobile phase consisted of an aqueous solution of calcium disodium ethylene diamine tetraacetate. The eluted constituents were detected by a refractometric detector and determined by the external standard method. The remaining plant material was subsequently dried at a temperature of $70^{\circ} \mathrm{C}$ until no more moisture content. After grinding the plant material, crude ash was determined gravimetrically, moisture content gravimetrically, fat by the Soxhlet method and dietary fibre by the Kürschner-Hanak method, while the caloric value was estimated by the conversion method using Atwater conversion factors. Total ash was determined quantitatively by grinding $2 \mathrm{~g}$ of the sample and combusting the material in a muffle furnace at $550^{\circ} \mathrm{C}$ to constant weight. The total ash content was calculated using the following formula:

$$
\%=\left(\mathrm{W}_{\mathrm{a}-100)} / \mathrm{W}_{\mathrm{r}} \text {------------- }(1)\right.
$$

where: $\mathrm{W}_{\mathrm{a}}$ - weight of the ash in $\mathrm{g}, \mathrm{W}_{\mathrm{r}}$-weight of the anhydrous raw material in $\mathrm{g}$.

The $40 \mathrm{~g}( \pm 1 \mathrm{mg})$ of homogeneous sample $\left(\mathrm{m}_{0}\right)$ grounded in mortar was mixed with $10 \mathrm{~g}$ of anhydrous sodium sulphate. The sample together with cotton swabbed resin was taken $3 / 4$ of extraction thimble height. The thimble was plugged with defatted cotton wool. The dry clean flask with several glass beads were weighted with accuracy of $\pm 1 \mathrm{mg}\left(\mathrm{m}_{1}\right)$. The flask poured with 350 $\mathrm{ml}$ of $\mathrm{n}$-hexane was placed in heated bath and connected with Soxhlet instrument. It was placed into extractor for 2.5 hours $(10 \mathrm{cycles} / \mathrm{h})$ than the cooled flask was weighed with an accuracy of $\pm 1 \mathrm{mg}\left(\mathrm{m}_{2}\right)$. The crude fat content, expressed in grams per $100 \mathrm{~g}$ of sample, was calculated according to the following formula:

$$
\mathrm{H}=\left\{\left(\mathrm{m}_{2}-\mathrm{m}_{1}\right) \times 100\right\} / \mathrm{m}_{0}
$$


where: $m_{0}$ - weight of the sample analyzed, $m_{1}$ - weight of the empty and clean flask containing glass beads, $\mathrm{m}_{2}-$ weight of the flask containing the extract and glass beads after it was dried and cooled to room temperature. All the weights were expressed in grams.

A solution of metaphosphoric acid was used to extract L-ascorbic acid from leaf. Dehydro-L+ ascorbic acid was converted to $\mathrm{L}+$ ascorbic acid using reducing solution and determined by HPLC with UV detection of $265 \mathrm{~nm}$ with detection limit of 1.5ugml-1. Flavonoid (quercetin equivalents) were measured spectrophotometrically on a Cary 50 Varian spectrophotometer (Polish Pharmacopoeia VIII, 2008). It had been extracted from leaf material and absorbance of solution was measured at wavelength of $425 \mathrm{~nm}$. This method has detection limit of $4.01 \mathrm{mg} 100 \mathrm{~g}-1$ and quantification limit was $4.76 \mathrm{mg} 100 \mathrm{~g}-1$. The following formula was used to expressed total flavonoid as quercetin equivalents.

$$
\mathrm{X}=(\mathrm{A} \times \mathrm{k}) / \mathrm{m}
$$

Where: $A$ is test solution absorbance, $\mathrm{K}$ is quercetin equivalents and $\mathrm{M}$ is quantity of plant material (g).

Glucosinolates (GL) were estimated using methanol and then purified and exposed to enzymatic desulfation on ion exchange resin. The GL content was measured on high performance liquid chromatograph (HPLC) attached with ultraviolet detector using gradient elution and reverse phase columns. The extracted GL was filtered through syringe filter and the sample was injected into chromatograph. The total GL content was determined as:

$\mathrm{TGL}=\left(\mathrm{A}_{\mathrm{g}} / \mathrm{m}_{\mathrm{s}}\right) \times(\mathrm{n} / \mathrm{m}) \times(100 / 100-\mathrm{w})$

Where: $\mathrm{A}_{\mathrm{g}}$-aggregate area of the peak with area $>1 \%$ of the total peak area in integrator units, $A_{s}$-peak area in integrator unit of desulfosinigrin, m-weight of analytical sample (g), n-amount of internal standard added to tube (umol) and w-moisture and volatile content as $\%$ of sample weight.

The essential oil content was calculated from leaf powdered material $(30 \mathrm{~g})$ by hydro-distillation in a Clevenger type apparatus following Farmakopea Polska VIII, 2008 guidelines. This method conducted once in 3 hours and conducted in three replications.

Physiological and visual quality under storage conditions: Leaves of rocket salad at commercial maturity were harvested from each fertilizer treatment field, immediately transported to salad processing facilities to be stored at 0,5 and $10^{\circ} \mathrm{C}$ temperature. Leaves were inspected for any kind of disease attack, washed with distilled water, centrifuged for the removal of remaining water and packed in polypropylene bags. The leaves were stored at 0,5 and $10^{\circ} \mathrm{C}$ temperature for storage period of 15 days and inspected after every 3 days. Respiration rate and concentrations of Oxygen and $\mathrm{CO}_{2}$ were calculated using Checkmate II (PBI Dan sensor, Ringsted, Demark) (Spadafora et al., 2016). The SPAD value of leaves was determined using portable chlorophyll meter (Konica Minolta SPAD-502; Minolta, Osaka, Japan) The SPAD value measurements were taken during each analysis day. The adaxial side of leaves were placed towards emitting window of the instrument while the major vein was avoided.

Statistical analysis: The collected data were analyzed statistically using one-way analysis of variance (ANOVA) to evaluate the level of significance. Tukey HSD at 5\% level of significance was applied to check the significant differences between the values of studied parameters. The complete statistical analysis was performed using Minitab 17 statistical software (Minitab Pty Ltd., Sydney, Australia). The results of three replications were presented with mean and Standard error.

\begin{tabular}{|c|c|c|c|c|c|c|}
\hline $\begin{array}{c}T_{1} \\
(\mathrm{CK})\end{array}$ & $\begin{array}{c}T_{2} \\
\left(N \Gamma_{K}\right)\end{array}$ & $\begin{array}{c}T_{3} \\
\text { (Or) }\end{array}$ & $\begin{array}{c}\mathrm{T}_{4} \\
\text { (HDr , Or) }\end{array}$ & $\begin{array}{c}T_{s} \\
\text { (HDI I HOr) }\end{array}$ & $\begin{array}{c}\mathrm{T}_{6} \\
\left(\mathrm{R} \Gamma_{\mathrm{K}}\right)\end{array}$ & $\begin{array}{c}\text { T, } \\
(R P K, N r)\end{array}$ \\
\hline $\begin{array}{c}\mathrm{T}_{7} \\
(\mathrm{RPK}+\mathrm{NF})\end{array}$ & $\begin{array}{c}T_{6} \\
\text { (RPK) }\end{array}$ & $\begin{array}{c}\mathrm{T}_{5} \\
(\mathrm{HDF}+\mathrm{HOF})\end{array}$ & $\begin{array}{c}\mathrm{T}_{4} \\
(\mathrm{HDF}+\mathrm{OF})\end{array}$ & $\begin{array}{c}T_{3} \\
(\mathrm{OF})\end{array}$ & $\begin{array}{c}\mathrm{T}_{2} \\
(\mathrm{NPK})\end{array}$ & $\begin{array}{c}T_{1} \\
(C K)\end{array}$ \\
\hline $\begin{array}{c}\mathrm{T}_{5} \\
\text { (HUト+HUト) }\end{array}$ & $\begin{array}{c}T_{3} \\
(U \vdash)\end{array}$ & $\begin{array}{c}\mathrm{T}_{4} \\
\text { (HUト+Uト) }\end{array}$ & $\begin{array}{c}T_{1} \\
\left(C_{K}\right)\end{array}$ & $\begin{array}{c}\mathrm{T}_{2} \\
(\mathrm{NPK})\end{array}$ & $\begin{array}{c}\mathrm{T}_{7} \\
(\mathrm{RPK}+\mathrm{Nr})\end{array}$ & $\begin{array}{c}T_{6} \\
(R P K)\end{array}$ \\
\hline
\end{tabular}

Figure 1. The experimental field layout.

\section{RESULTS}

Growth characteristics yield and seed quality: The statistical analysis of variance exhibited the significant influence of long-term fertilizer options on plant growth and fruit development characteristics of Eruca plants (Table 4). Different fertilizer options (organic and inorganic) influenced plant height and root length $(\mathrm{cm})$, the number of branches and siliqua per plant, siliqua length with the number of seed, 1000 seed weight, and seed yield. Lee (2010), reported the same response in rocket plants. The integrated application of organic (FYM) and inorganic (NPK) fertilizers enhanced plant morphological growth and seed yield like the plots fed with $(\mathrm{HDF}+\mathrm{OF})$ fertilizer option produced significantly maximum results. The plots fertilized with organic 
(NPK), organic (FYM) and mixed half dose of each (HDF+OF) didn't show significantly different results while RPK and RPK +NF gave lowest results among fertilizer options but more than that of $\mathrm{CK}$ (no fertilizer).

The tallest plants $(112.09 \pm 0.84 \mathrm{~cm})$ were produced with $\mathrm{HDF}+\mathrm{OF}$ which wasn't statistically different from $(107.58 \pm 1.13 \mathrm{~cm})$ with $\mathrm{OF}$ followed by $(105.85 \pm 1.42 \mathrm{~cm})$ with RDF and the shortest plants $(83.82 \pm 3.87 \mathrm{~cm})$ were observed in $\mathrm{CK}$ (no fertilizer) during all crop periods. The gradual increase in plant height was observed with increment in the dose and higher uptake of $\mathrm{N}$. The maximum branches per plant $(23.3 \pm 0.31)$, root length $(20.33 \pm 1.52 \mathrm{~cm})$, number of siliquae per plant $(192.93 \pm 25.44)$ and siliqua length $(5.4 \pm 0.07 \mathrm{~cm})$ were recorded from the fertilizer treatment (HDF+OF), which was significantly different from other fertilizer and controlled options. The maximum number of seeds/siliqua $(27.97 \pm 0.14), 1000$ seed weight $(1.9 \pm 0.06 \mathrm{~g})$ and seed yield $(1371.9 \pm 0.67 \mathrm{~kg} / \mathrm{ha})$ were yielded where plants fed with integrated organic and inorganic fertilizers $(\mathrm{HDF}+\mathrm{OF})$ options. The plots with RDF and OF fertilizer options didn't produced significantly different number of seeds per siliqua while the significantly different for 1000 seed weight and seed yield were obtained.

The disease index to evaluate the resistance of taramira plants were based on a $0-9$ scale $(0-3=$ Resistant, 3-6 = moderate resistant and 6-9 = susceptible). The ANOVA was performed for disease index data using Stat Macros software.

Evaluation of powdery mildew resistance: $\mathrm{S}=$ susceptible; $\mathrm{M}=$ moderate resistance; $\mathrm{R}=$ resistant and $\mathrm{RE}=$ resistance evaluation .

The seed quality of eruca sativa leaves, as determined by the oil content, protein, glucosinolates, oleic acid, Linolic acid, and Euric acid was high and significantly affected by fertilizer strategies applied (Table 6). The average oil content from 2015-16 to 201819 contained in the Eruca seeds under different fertilizer options ranged from $33.61 \pm 0.16-37.73 \pm 1.34 \%$ and oil content under $\mathrm{CK}$ was $32.09 \pm 0.4 \%$. In general, $\mathrm{HDF}+\mathrm{OF}$ and OF options exhibited higher oil contents $37.73 \pm 1.34 \% \quad(517.62 \pm 0.25 \mathrm{~kg} / \mathrm{ha})$ and $37.18 \pm 0.35 \%$ $(463.1 \pm 0.69 \mathrm{~kg} / \mathrm{ha})$ as compared to those of other fertilizer strategies. CK, by and large, had low oil content. The protein content in the seeds also exhibited significant variability among all fertilizer options during the entire experiment. The seed contained high protein content was from the plants with fertilizer options $\mathrm{HDF}+\mathrm{OF}$ and $\mathrm{HDF}+\mathrm{HOF}$. The RDF, RPK, and RPK+NF showed similar protein contents in the seed. Glucosinolates content in all the treatments except CK and RPK was much higher while $\mathrm{HDF}+\mathrm{OF}(10.28 \pm 0.05$ $\mu \mathrm{g} / \mathrm{mol})$ and $\mathrm{HDF}+\mathrm{HOF}(9.94 \pm 0.05 \mu \mathrm{g} / \mathrm{mol})$ showed significantly maximum values than RDF. Glucosinolates concentration in the seed is associated with the application of S chemical element. Considerably higher concentrations of glucosinolates in seed were observed in $\mathrm{HDF}+\mathrm{OF}$ and $\mathrm{HDF}+\mathrm{HOF}$ than others in all years. The essential fatty acids including oleic acid $(38.28 \pm 0.65 \%)$, Linolic acid (5.91 $\pm 0.23 \%)$ and Euric acid (57.54 $\pm 0.45 \%)$ were found significant under $\mathrm{HDF}+\mathrm{OF}$ options in all years of experiment.

The powdery mildew resistance test conducted by detached cotyledons incubated at $20^{\circ} \mathrm{C}$ revealed that the leaves collected from plants fed with fertilizer options contained organic matter at any stage $\left(1^{\text {st }}, 7^{\text {th }}\right.$ and $15^{\text {th }}$ leaf) were found most resistant during all cropping seasons. The symptoms on the plant leaf under organic fertilizer options were nearly undetachable because they exhibited very few sporulations. RDF and CK plant's leaves showed moderate resistance to powdery mildew. The plants fed with $\mathrm{RPK}+\mathrm{NF}$ were resistant at first and seventh leaf stage and moderately resistant at $15^{\text {th }}$ leaf stage while, in RPK fertilizer option, plants resistance only at first leaf stage.

Bioactive substance, nutritional and energetic values in Eruca leaves: The fresh matter yield of Eruca $\left(53.30 \pm 0.88\right.$ g plant $\left.^{-1}\right)$ was significantly maximum in plot fed with integrated fertilizer $(\mathrm{HDF}+\mathrm{OF})$ than all other fertilizer options and control $\mathrm{CK}$. The plants received $\mathrm{OF}$ \& $\mathrm{HDF}+\mathrm{HOF}, \mathrm{CK} \& \mathrm{RDF}$, and $\mathrm{RPK} \& \mathrm{RPK}+\mathrm{NF}$ fertilizers were characterized non-significant in plant fresh matter yield while lowest figures were in CK during all crop seasons. Eruca leaves are a valuable product containing a significant proportion of leaf dry matter (Nurzyńska-Wierdak, 2015). The leading dry matter $(9.57 \pm 0.24 \%)$ was measured in OF options while the lowest $(8.21 \pm 0.17 \%)$ was in plot fed with $\mathrm{HDF}+\mathrm{OF}$ fertilizer option. The plant leaves in $\mathrm{HDF}+\mathrm{OF}$ were characterized by a maximum L-ascorbic acid

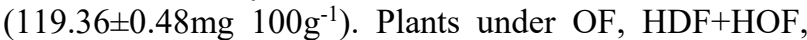
and $\mathrm{RPK}+\mathrm{NF}$ showed significantly similar values of $\mathrm{L}$ ascorbic acid while the lowest values were associated with RDF and CK in all experimental years. The highest chlorophyll content $(0.73 \pm 0.01 \mathrm{mg})$ per $100 \mathrm{~g}$ of the fresh matter was measured in plant leaf fed with $\mathrm{HDF}+\mathrm{OF}$ fertilizer option. The $\mathrm{OF}$ and $\mathrm{HDF}+\mathrm{HOF}$ also produced better chlorophyll contents, while RDF and CK showed the lowest chlorophyll content. The chlorophyll content in the fresh matter must be high to enhance its nutritional and health-promoting values. Moreover, the chlorophyll content in green leafy vegetables can be used to estimate the concentration of lutein and $\beta$-carotene.

The other bioactive substance of Eruca leaves were also al relatively high level. Plant leaves fed with integrated $\mathrm{HDF}+\mathrm{OF}$ fertilizer option contained flavonoids $(0.90 \pm 0.00 \mathrm{~g})$ and essential oil $(0.16 \pm 0.00 \mathrm{ml})$ per $100 \mathrm{~g}$ of dried matter, while $1 \mathrm{~g}$ of dry matter was characterized by the presence of maximum $17.18 \pm 0.09 \mu$-mol of glucosinolates. 
Table 4. Effect of sole and integrated fertilizer strategies on plant growth and yield characteristics (2015-16 to 2018-19).

\begin{tabular}{|c|c|c|c|c|c|c|c|c|}
\hline Treatment & $\begin{array}{c}\text { Plant } \\
\text { Height, } \mathrm{cm}\end{array}$ & $\begin{array}{c}\text { Branches } \\
\text { Plant }^{-1}\end{array}$ & $\begin{array}{c}\text { Root Length, } \\
\text { cm }\end{array}$ & $\begin{array}{l}\text { Number of } \\
\text { siliqua/plant }\end{array}$ & $\begin{array}{c}\text { Siliqua length, } \\
\mathrm{cm}\end{array}$ & $\begin{array}{c}\text { Number of } \\
\text { Seeds/siliqua }\end{array}$ & $\begin{array}{l}1000 \text { seed } \\
\text { weight, g }\end{array}$ & $\begin{array}{c}\text { Seed yield, } \\
\mathrm{kg} / \mathrm{ha}\end{array}$ \\
\hline $\mathrm{CK}$ & $83.82 \pm 3.87$ & $7.65 \pm 0.45$ & $14.42 \pm 0.30$ & $93.45 \pm 8.77$ & $3.05 \pm 0.02$ & $17.72 \pm 0.74$ & $1.20 \pm 0.04$ & $829.93 \pm 25.40$ \\
\hline RDF & $105.85 \pm 1.42$ & $15.55 \pm 0.45$ & $17.72 \pm 1.70$ & $150.12 \pm 19.12$ & $4.82 \pm 0.15$ & $24.05 \pm 0.54$ & $1.66 \pm 0.03$ & $1191.12 \pm 31.02$ \\
\hline OF & $107.58 \pm 1.13$ & $16.65 \pm 0.23$ & $17.93 \pm 0.37$ & $163.47 \pm 12.76$ & $5.17 \pm 0.04$ & $24.49 \pm 0.39$ & $1.75 \pm 0.00$ & $1246.88 \pm 12.85$ \\
\hline $\mathrm{HDF}+\mathrm{OF}$ & $112.09 \pm 0.84$ & $23.30 \pm 0.31$ & $20.33 \pm 1.52$ & $192.93 \pm 25.44$ & $5.40 \pm 0.07$ & $27.97 \pm 0.14$ & $1.90 \pm 0.06$ & $1371.9 \pm 9.67$ \\
\hline $\mathrm{HDF}+\mathrm{HOF}$ & $100.15 \pm 0.61$ & $14.40 \pm 0.21$ & $18.11 \pm 0.37$ & $150.45 \pm 10.05$ & $4.75 \pm 0.09$ & $22.72 \pm 0.28$ & $1.46 \pm 0.00$ & $1021.91 \pm 15.06$ \\
\hline RPK & $93.10 \pm 3.87$ & $11.95 \pm 0.23$ & $18.46 \pm 0.71$ & $125.90 \pm 12.96$ & $4.17 \pm 0.07$ & $19.52 \pm 0.46$ & $1.30 \pm 0.01$ & $946.66 \pm 8.82$ \\
\hline $\mathrm{RPK}+\mathrm{NF}$ & $97.58 \pm 4.27$ & $14.72 \pm 0.17$ & $15.98 \pm 0.42$ & $133.00 \pm 10.49$ & $4.72 \pm 0.11$ & $22.12 \pm 0.51$ & $1.55 \pm 0.00$ & $1047.83 \pm 20.39$ \\
\hline
\end{tabular}

The given values are mean of three crop seasons 2015-16 to 2018-19 with standard error.

Table 5. Effect of different fertilizer strategies on powdery mildew resistance (2015-16 to 2018-19).

\begin{tabular}{|c|c|c|c|}
\hline \multirow{2}{*}{ Treatment } & \multicolumn{3}{|c|}{ Disease Index } \\
\hline & 1st true leaf (RE) & 7th true leaf (RE) & 15th true leaf (RE) \\
\hline CK & $3.03 \pm 0.25(\mathrm{M})$ & $5.88 \pm 0.47(\mathrm{M})$ & $5.30 \pm 0.31(\mathrm{M})$ \\
\hline $\mathrm{RDF}$ & $3.08 \pm 0.25(\mathrm{M})$ & $3.35 \pm 0.26(\mathrm{M})$ & $3.83 \pm 0.43(\mathrm{M})$ \\
\hline $\mathrm{OF}$ & $2.39 \pm 1.45(\mathrm{R})$ & $2.68 \pm 1.25(\mathrm{R})$ & $2.98 \pm 1.5(\mathrm{R})$ \\
\hline $\mathrm{HDF}+\mathrm{OF}$ & $1.43 \pm 1.05(\mathrm{R})$ & $2.05 \pm 1.1(\mathrm{R})$ & $2.48 \pm 1.5(\mathrm{R})$ \\
\hline $\mathrm{HDF}+\mathrm{HOF}$ & $2.34 \pm 0.16(\mathrm{R})$ & $2.78 \pm 0.04(\mathrm{R})$ & $2.90 \pm 0.3(\mathrm{R})$ \\
\hline RPK & $2.78 \pm 0.66(\mathrm{R})$ & $3.29 \pm 0.64(\mathrm{M})$ & $3.94 \pm 0.29(\mathrm{M})$ \\
\hline $\mathrm{RPK}+\mathrm{NF}$ & $2.48 \pm 0.12(\mathrm{R})$ & $2.72 \pm 0.2(\mathrm{R})$ & $3.25 \pm 0.4(\mathrm{M})$ \\
\hline
\end{tabular}

The given values are mean of yearly means from crop seasons 2015-16 to 2018-19 with standard error.

Table 6. Effect of different fertilizer strategies on seed quality (2015-16 to 2018-19).

\begin{tabular}{|c|c|c|c|c|c|c|c|}
\hline Treatment & Oil Content (\%) & Oil Yield (kg/ha) & $\begin{array}{c}\text { Protein Content } \\
(\%)\end{array}$ & $\begin{array}{c}\text { Glucosinolates Content } \\
(\mu \mathrm{g} / \mathrm{mol})\end{array}$ & Oleic Acid (\%) & Linolic Acid (\%) & Euric Acid (\%) \\
\hline CK & $32.09 \pm 0.40$ & $266.32 \pm 8.15$ & $20.35 \pm 0.23$ & $8.39 \pm 0.08$ & $22.96 \pm 0.41$ & $4.62 \pm 0.26$ & $26.80 \pm 0.12$ \\
\hline $\mathrm{RDF}$ & $35.43 \pm 1.84$ & $422.02 \pm 10.99$ & $24.97 \pm 0.16$ & $9.44 \pm 0.32$ & $29.91 \pm 1.32$ & $6.08 \pm 0.07$ & $48.14 \pm 2.84$ \\
\hline OF & $37.18 \pm 0.35$ & $463.1 \pm 0.69$ & $21.19 \pm 0.20$ & $9.07 \pm 0.11$ & $33.77 \pm 0.15$ & $4.31 \pm 10$ & $40.69 \pm 0.78$ \\
\hline $\mathrm{HDF}+\mathrm{OF}$ & $37.73 \pm 1.34$ & $517.62 \pm 0.25$ & $28.18 \pm 0.93$ & $10.28 \pm 0.05$ & $38.28 \pm 0.65$ & $5.91 \pm 0.23$ & $57.54 \pm 0.45$ \\
\hline $\mathrm{HDF}+\mathrm{HOF}$ & $35.29 \pm 0.22$ & $360.63 \pm 0.72$ & $28.23 \pm 0.41$ & $9.94 \pm 0.05$ & $36.90 \pm 0.70$ & $5.66 \pm 0.23$ & $52.50 \pm 2.99$ \\
\hline RPK & $33.61 \pm 0.16$ & $318.17 \pm 2.96$ & $23.53 \pm 0.21$ & $8.51 \pm 0.08$ & $27.10 \pm 0.23$ & $4.57 \pm 0.05$ & $35.60 \pm 1.67$ \\
\hline $\mathrm{RPK}+\mathrm{NF}$ & $34.61 \pm 0.21$ & $362.65 \pm 10.48$ & $24.73 \pm 0.22$ & $9.46 \pm 0.03$ & $30.33 \pm 0.38$ & $3.52 \pm 0.13$ & $45.11 \pm 2.39$ \\
\hline
\end{tabular}

The given values are mean of yearly means from crop seasons 2015-16 to 2018-19 with standard error. 
Table 7. Bioactive substance in plant leaves upon different fertilizer strategies (2015-16 to 2018-19).

\begin{tabular}{|c|c|c|c|c|c|c|c|}
\hline Treatment & $\begin{array}{c}\text { Fresh matter, } \\
\text { g plant }^{-1} \\
\end{array}$ & $\begin{array}{l}\text { Dry matter*, } \\
\text { (DM) \% }\end{array}$ & $\begin{array}{c}\text { L-ascorbic acid, } \\
{\text { mg } 100 \mathrm{~g}^{-1} \mathrm{FM}}\end{array}$ & $\begin{array}{c}\text { Chlorophyll, mg } \\
\mathbf{1 0 0 g}^{-1} \text { FM }\end{array}$ & $\begin{array}{c}\text { Glucosinolates, } \\
\mu \mathrm{mol} \mathrm{g}^{-1} \mathrm{DM}\end{array}$ & $\begin{array}{c}\text { Flavonoids, g } 100 \\
\mathrm{~g}^{-1} \mathrm{DM} \\
\end{array}$ & $\begin{array}{c}\text { Essential oil, ml } \\
100 \mathrm{~g}^{-1} \mathrm{DM} \\
\end{array}$ \\
\hline $\mathrm{CK}$ & $31.60 \pm 0.36$ & $8.93 \pm 0.06$ & $55.32 \pm 1.62$ & $0.39 \pm 0.01$ & $8.25 \pm 0.12$ & $0.70 \pm 0.01$ & $0.09 \pm 0.00$ \\
\hline $\mathrm{RDF}$ & $31.60 \pm 0.25$ & $8.93 \pm 0.15$ & $55.32 \pm 1.39$ & $0.39 \pm 0.02$ & $8.25 \pm 0.12$ & $0.70 \pm 0.01$ & $0.09 \pm 0.01$ \\
\hline OF & $47.98 \pm 0.67$ & $9.57 \pm 0.24$ & $110.45 \pm 0.35$ & $0.57 \pm 0.01$ & $15.76 \pm 0.14$ & $0.86 \pm 0.00$ & $0.13 \pm 0.00$ \\
\hline $\mathrm{HDF}+\mathrm{OF}$ & $53.30 \pm 0.88$ & $8.21 \pm 0.17$ & $119.36 \pm 0.48$ & $0.73 \pm 0.01$ & $17.18 \pm 0.09$ & $0.90 \pm 0.00$ & $0.16 \pm 0.00$ \\
\hline $\mathrm{HDF}+\mathrm{HOF}$ & $44.93 \pm 0.83$ & $8.79 \pm 0.06$ & $99.77 \pm 0.52$ & $0.51 \pm 0.01$ & $11.79 \pm 0.12$ & $0.77 \pm 0.01$ & $0.12 \pm 0.00$ \\
\hline RPK & $40.53 \pm 0.79$ & $10.88 \pm 0.24$ & $76.85 \pm 0.31$ & $0.43 \pm 0.00$ & $8.71 \pm 0.17$ & $0.81 \pm 0.01$ & $0.10 \pm 0.00$ \\
\hline $\mathrm{RPK}+\mathrm{NF}$ & $41.53 \pm 0.43$ & $10.33 \pm 0.15$ & $100.77 \pm 0.47$ & $0.50 \pm 0.01$ & $13.19 \pm 0.23$ & $0.81 \pm 0.00$ & $0.12 \pm 0.00$ \\
\hline
\end{tabular}

*(Nurzyńska-Wierdak, 2015).

The given values are mean of yearly means from crop seasons 2015-16 to 2018-19 with standard error

Table 8. Nutritional and Energetic values in plant leaves upon different fertilizer strategies (2015-16 to 2018-19).

\begin{tabular}{|c|c|c|c|c|c|c|c|c|c|}
\hline \multirow[b]{2}{*}{ Treatment } & Moisture & Ash & Fat & Fibre & \multirow{2}{*}{$\begin{array}{c}\text { Carbohydrates, } \\
\% \text { FM }^{*}\end{array}$} & \multirow{2}{*}{$\begin{array}{c}\text { Digestive } \\
\text { carbohydrates, \% } \\
\text { FM }\end{array}$} & Glucose & Fructose & \multirow{2}{*}{$\begin{array}{c}\text { Energetic value, kJ } \\
\qquad 100 \mathrm{~g}^{-1}\end{array}$} \\
\hline & \multicolumn{4}{|c|}{$\% \mathrm{DM}$} & & & \multicolumn{2}{|c|}{ g $100 g^{-1}$ FM } & \\
\hline $\mathrm{CK}$ & $8.11 \pm 0.13$ & $19.75 \pm 0.3$ & $3.80 \pm 0.05$ & $13.39 \pm 0.11$ & $34.83 \pm 0.48$ & $20.78 \pm 0.48$ & $0.93 \pm 0.01$ & $0.69 \pm 0.01$ & $1022.25 \pm 1.36$ \\
\hline $\mathrm{RDF}$ & $8.11 \pm 0.08$ & $19.75 \pm 0.4$ & $3.80 \pm 0.06$ & $13.39 \pm 0.24$ & $44.10 \pm 1.07$ & $34.40 \pm 0.27$ & $2.20 \pm 0.01$ & $1.73 \pm 0.01$ & $1066.73 \pm 1.73$ \\
\hline $\mathrm{OF}$ & $8.09 \pm 0.09$ & $19.13 \pm 0.1$ & $3.95 \pm 0.05$ & $15.61 \pm 0.12$ & $43.18 \pm 0.46$ & $33.80 \pm 0.34$ & $2.16 \pm 0.01$ & $1.72 \pm 0.01$ & $1061.30 .2 \pm 1.84$ \\
\hline $\mathrm{HDF}+\mathrm{OF}$ & $8.04 \pm 0.18$ & $18.25 \pm 0.23$ & $3.95 \pm 0.1$ & $16.65 \pm 0.24$ & $52.30 \pm 1.44$ & $38.20 \pm 0.59$ & $2.15 \pm 0.02$ & $1.77 \pm 0.01$ & $1080.55 \pm 2.75$ \\
\hline $\mathrm{HDF}+\mathrm{HOF}$ & $7.76 \pm 0.19$ & $19.73 \pm 0.11$ & $4.02 \pm 0.07$ & $14.54 \pm 0.1$ & $39.20 \pm 0.81$ & $30.75 \pm 0.63$ & $1.66 \pm 0.04$ & $1.43 \pm 0$ & $1047.80 \pm 2.37$ \\
\hline RPK & $7.88 \pm 0.1$ & $20.77 \pm 0.32$ & $3.79 \pm 0.09$ & $13.91 \pm 0.19$ & $37.45 \pm 0.29$ & $25.83 \pm 0.31$ & $1.36 \pm 0.01$ & $1.33 \pm 0.01$ & $1040.30 \pm 1.27$ \\
\hline $\mathrm{RPK}+\mathrm{NF}$ & $7.96 \pm 0.13$ & $19.66 \pm 0.12$ & $3.75 \pm 0.04$ & $14.15 \pm 0.15$ & $37.93 \pm 0.72$ & $28.53 \pm 0.48$ & $1.63 \pm 0.05$ & $1.40 \pm 0.01$ & $1047.23 \pm 1.72$ \\
\hline
\end{tabular}

*-FM-fresh matter

The given values are mean of yearly means from crop seasons 2015-16 to 2018-19 with standard error 
The nutritional values of eruca leaves, as measured by the content of fat, dietary fibre, ash, and carbohydrates, was high and significantly affected by fertilizer options as shown in Table 8. The examined plants were characterized by the following percentages of individual components (on average in the leaf dry matter): $3.86 \%$ of fat, $14.38 \%$ of dietary fibre, $19.58 \%$ of ash, $7.99 \%$ of moisture content, $41.28 \%$ of carbohydrates, including $30.33 \%$ of available carbohydrates.

Some of the nutrients were significantly influenced by different soil fertilizer options (Table 8). The plants fed with $\mathrm{OF}$ and $\mathrm{HDF}+\mathrm{OF}$ fertilizer options were characterized by higher fat content, dietary fibre, and carbohydrates concentration as compared with that of other fertilizer strategies. Similar results regarding carbohydrates were discussed in previous studies (Nurzyńska-Wierdak, 2009). The leaves of the plant under treatments $\mathrm{HDF}+\mathrm{HOF}, \mathrm{RPK}$ and $\mathrm{RPK}+\mathrm{NF}$ significantly influenced ash content but, didn't influence moisture content. Plants under the treatments of organic fertilizer than inorganic gave higher moisture content but, plants fed with RDF fertilizer had similar glucose concentration $(2.20 \pm 0.01 \mathrm{~g} 100 \mathrm{~g}-1 \mathrm{FM})$ as $\mathrm{OF}(2.16 \pm 0.01$ g 100g-1 FM) and HDF+OF $(2.15 \pm 0.02$ g 100g-1 FM $)$ at every year of the experiment. Like carbohydrates concentration, the fructose contents in $\mathrm{HDF}+\mathrm{OF}$

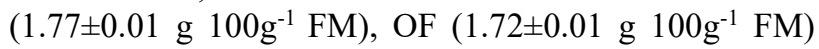

and RDF $\left(1.73 \pm 0.01 \mathrm{~g}^{100 \mathrm{~g}^{-1}} \mathrm{FM}\right)$ didn't show a significant difference. The energetic value of $100 \mathrm{~g}$ of dry eruca leaf matter was on average $1052.31 \mathrm{~kJ}$ which wasn't dependent on plant nutrition application level.

Physiological and visual quality under storage: Storage conditions (temperature and storage time) significantly influenced the physiological and visual quality of eruca leaves as shown in Figure 2(a-d). Carbon dioxide production was significantly lower when eruca leaves were stored at $0^{\circ} \mathrm{C}$ compared with $10^{\circ} \mathrm{C}$. Oxygen and carbon dioxide concentrations inside leaves packages were also significantly affected by the storage conditions as presented in Figure $2(b \& c)$. leaves stored at higher temperatures $\left(5\right.$ and $\left.10^{\circ} \mathrm{C}\right)$ gave significantly quick $\mathrm{O}_{2}$ depletion and $\mathrm{CO}_{2}$ accumulation levels as compared to $0^{\circ} \mathrm{C}$ during the first 6 days of storage. After 9 days $\mathrm{CO}_{2}$ levels from the leaves package at higher temperatures were similar which were only significantly different from those stored at $0^{\circ} \mathrm{C}$ and by 15 days although differences were still significant. The chlorophyll contents were recorded as an indicator of the progression of senescence. There were significant changes in chlorophyll concentration over the storage period as shown in Figure 2(d) both between days of storage and temperatures of storage.

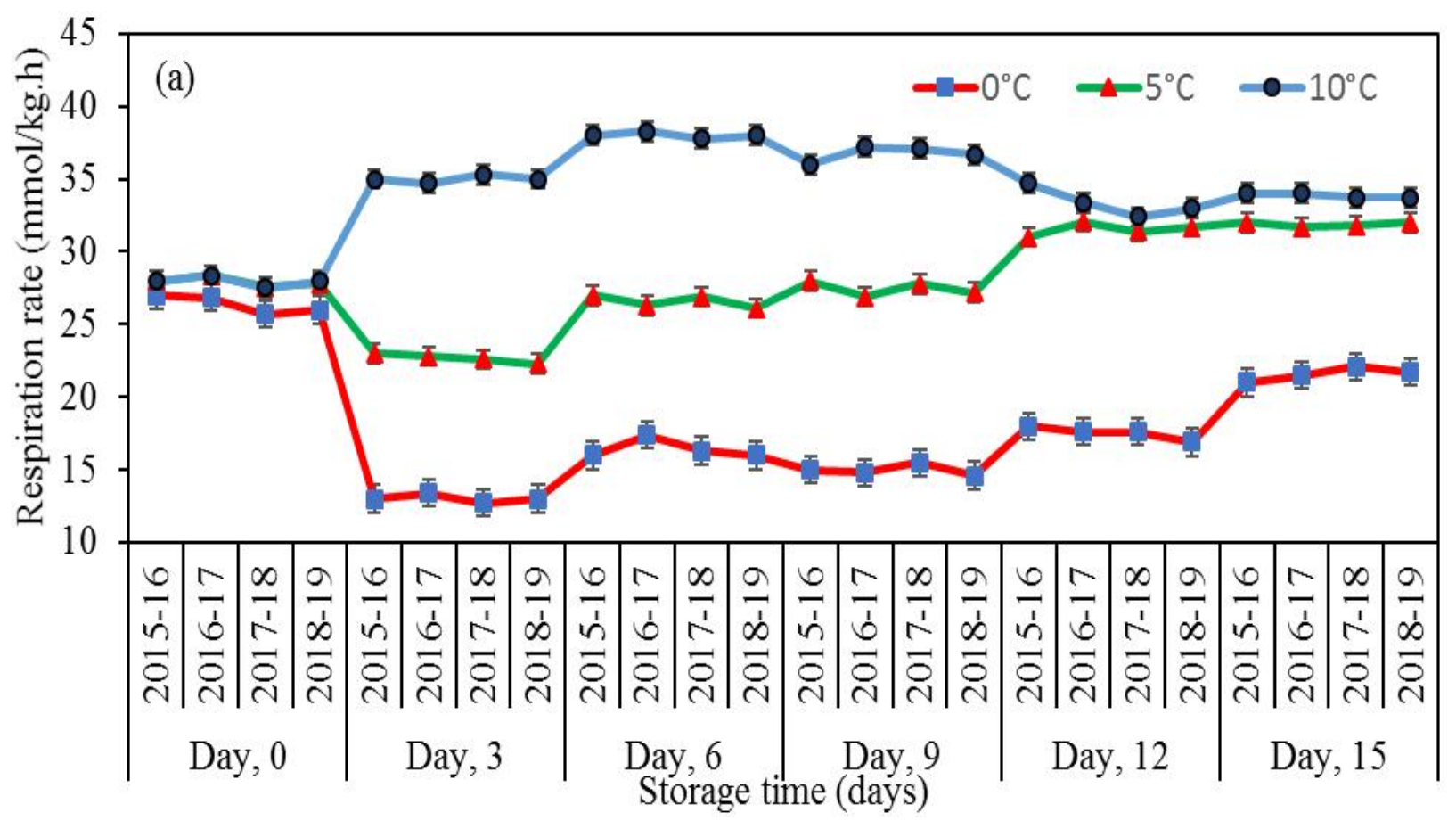



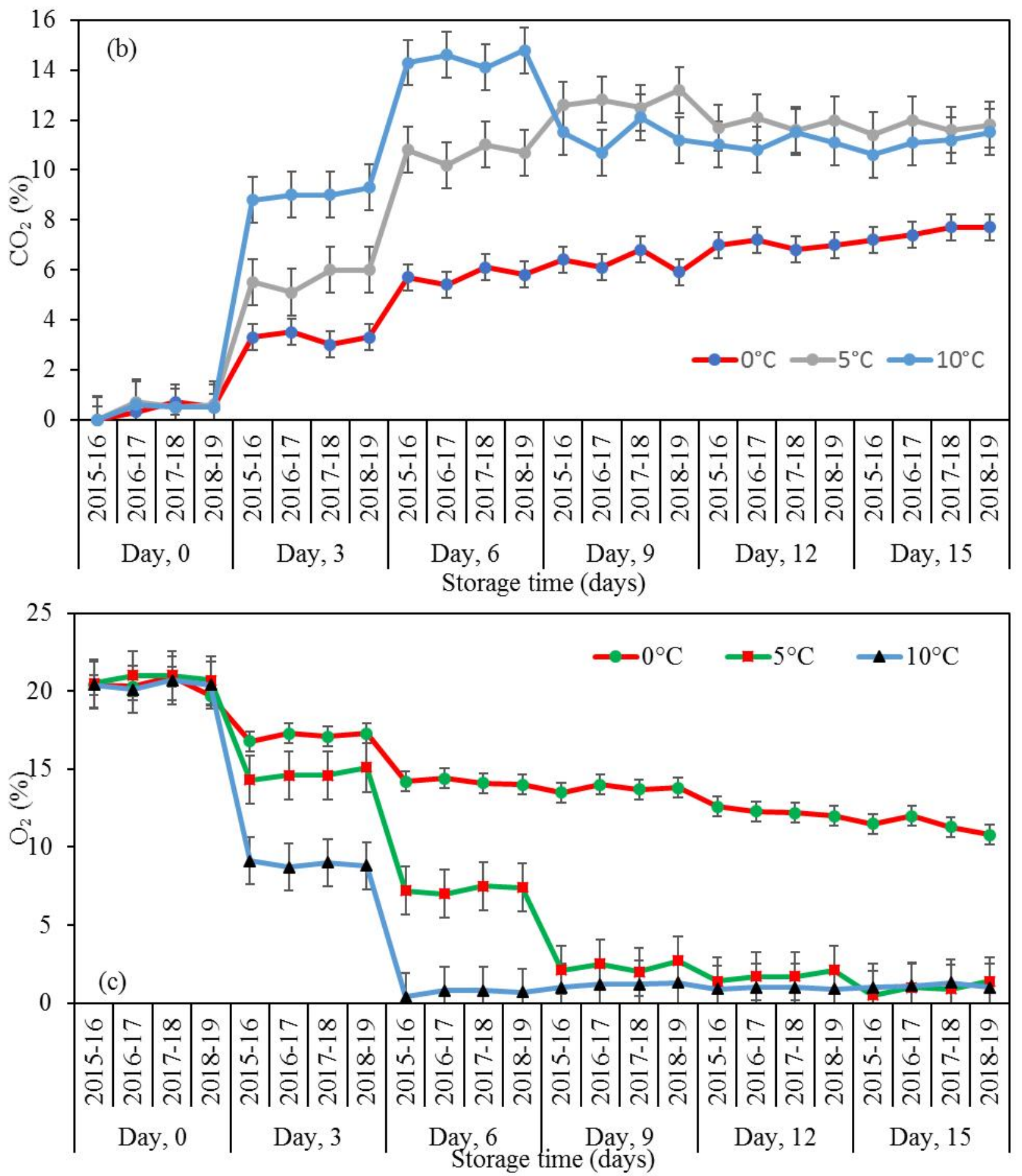


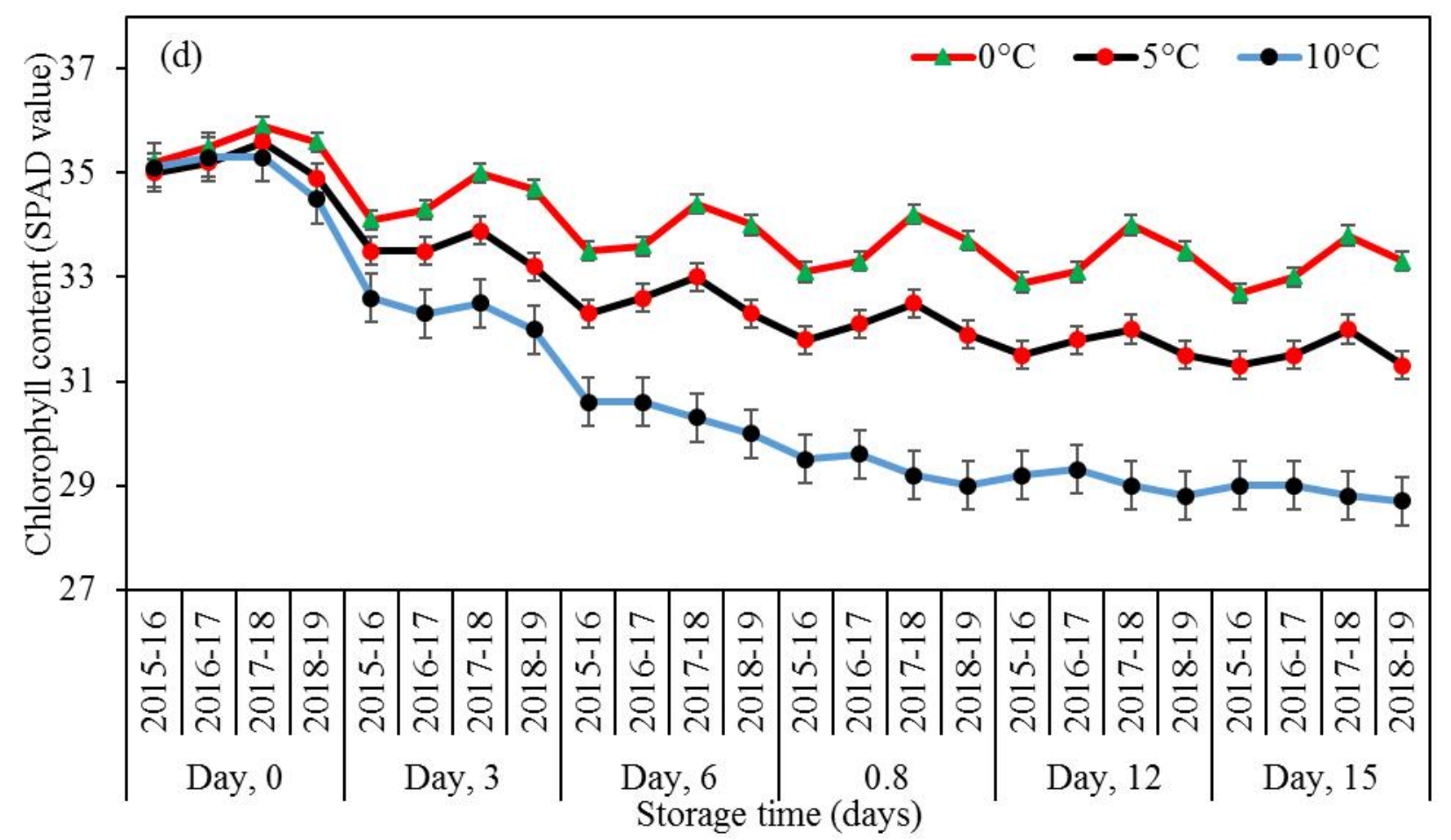

Figure 2(a-d): Effect of different fertilizer strategies on physiological and biological characteristics: (a) respiration rate, (b) $\mathrm{CO}_{2}$, (c) $\mathrm{O}_{2}$, (d) chlorophyll content in leaves stored at $0^{\circ} \mathrm{C}, 5^{\circ} \mathrm{C}$ and $10^{\circ} \mathrm{C}$ during 15 days of storage (mean \pm standard error; $n=3)$. ANOVA and Tukey's range test $(P \leq 0.05)$ was performed.

Soil chemical health: The bulk density $(\mathrm{Db})$ of the surface soil layer $(0-15$ and $15-30 \mathrm{~cm}$ depths), were $1.5 \pm 0.07$ and $1.53 \pm 0.05 \mathrm{Mgm}^{-3}$, respectively, at the commencement of experiment. However, increased with an increasing soil depth, measuring $1.62 \pm 0.04 \mathrm{Mgm}^{-3}$ at a depth of 45-60 cm. at the end of terminal year (2018-19), the organic fertilizer options didn't influence the soil $\mathrm{Db}$ in the soil depths $(0-15$ and $15-30 \mathrm{~cm})$, but the $\mathrm{Db}$ values in RDF were increased to $1.54 \pm 0.01$ and $1.63 \pm 0.02 \mathrm{Mgm}^{-}$ ${ }^{3}$ at soil depths (0-15 and $15-30 \mathrm{~cm}$ depths), respectively. The other soil properties electrical conductivity (EC) and soil $\mathrm{pH}$ didn't show significant changes under integrated fertilizer option compared with chemical fertilizer options.

Soil organic carbon content (SOC). The SOC contents were measured at profile depths of $0-15$ and $15-30 \mathrm{~cm}$ during entire experiment 2015-16 to 2018-19 varied in accordance with the soil depth and with the passage of time as presented in Table 9 . In upper soil layer $(0-15 \mathrm{~cm}$ depth) after 2015-16 season, the SOC content was measured highest $\left(5.9 \mathrm{~g} \mathrm{~kg}^{-1}\right)$ under OF option which was on par with $\mathrm{HDF}+\mathrm{OF}\left(5.8 \mathrm{~g} \mathrm{~kg}^{-1}\right)$ and $\mathrm{HDF}+\mathrm{HOF}(5.6 \mathrm{~g}$ $\left.\mathrm{kg}^{-1}\right)$, though statistically higher $(p \leq 0.05)$ than RDF $\left(5.3 \mathrm{~g} \mathrm{~kg}^{-1}\right)$ and $\mathrm{CK}\left(4.8 \mathrm{~g} \mathrm{~kg}^{-1}\right)$. The SOC contents increased $(p \leq 0.05)$ under all fertilizer treatments containing organic component over the years but declined in controlled (CK). The SOC remained nearly unaffected different years of study. During the terminal year of study (2018-19), the highest SOC $\left(7.5 \mathrm{~g} \mathrm{~kg}^{-1}\right)$ was observed under $\mathrm{HDF}+\mathrm{OF}$ fertilizer option followed by observed under OF $\left(7.3 \mathrm{~g} \mathrm{~kg}^{-1}\right)$ which were significantly higher $(p \leq$ $0.05)$ than that under HDF+HOF $\left(6.6 \mathrm{~g} \mathrm{~kg}^{-1}\right)$ and RDF $\left(5.3 \mathrm{~g} \mathrm{~kg}^{-1}\right)$. Inorganic fertilizers and controlled options had significantly $(p \leq 0.05)$ lower SOC contents than that under organic and integrated fertilizer options. The SOC content also varied with soil depth, a relatively lower SOC contents were measured at the $15-30 \mathrm{~cm}$ depth. At this soil depth, $\mathrm{HDF}+\mathrm{OF}$ and $\mathrm{OF}$ had significantly similar SOC contents and maximum than that under $\mathrm{HDF}+\mathrm{HOF}$, $\mathrm{RDF}, \mathrm{CK}$ and other fertilizer options in different crop seasons. The SOC contents measured after multiple crop year concerning the onset of the experiment, showed improvement at both soil depths under pure organic and integrated organic fertilizer options.

Soil mineral $\mathbf{N}$ content. The nitrate $\left(\mathrm{NO}_{3}\right)-\mathrm{N}$ content in the soil $(0-15 \mathrm{~cm}$ depth) was highest under $\mathrm{HDF}+\mathrm{OF}$ compared with all other fertilizer management options and controlled; the differences were more prominent during all cropping years as shown in Table 10. The $\left(\mathrm{NO}_{3}\right)-\mathrm{N}$ contents in surface soil layer under $\mathrm{HDF}+\mathrm{OF}$ fertilizer option were higher than RDF by $100 \%$ in 2015 $16,150 \%$ in $2016-17,152 \%$ in $2017-18$ and $123 \%$ in 2018-19. The corresponding increases with the inclusion of farmyard manure $(\mathrm{HDF}+\mathrm{OF})$ were $75 \%, 90 \%, 98 \%$ 
and $100 \%$, respectively. compared with the initial $\left(\mathrm{NO}_{3}\right)$ $\mathrm{N}$ content in the surface soil $\left(7.1 \pm 0.18 \mathrm{mg} \mathrm{kg}^{-1}\right)$, the $\left(\mathrm{NO}_{3}\right)-\mathrm{N}$ contents in $\mathrm{HDF}+\mathrm{HOF}, \mathrm{RPK}+\mathrm{NF}, \mathrm{HDF}+\mathrm{OF}$ and $\mathrm{OF}$ options were greater by 7.36, 7.26, 14.5 and $11.6 \mathrm{mg} \mathrm{kg}^{-1}$, respectively, during terminal year. On the other hand, CK and RDF led to depletion of $\left(\mathrm{NO}_{3}\right)-\mathrm{N}$ content by 2.8 and $1.71 \mathrm{mg} \mathrm{kg}^{-1}$, respectively, over the initial status. Different fertilizer options significantly influenced $\left(\mathrm{NO}_{3}\right)-\mathrm{N}$ content pattern in the soil profile. Whereas, the $\left(\mathrm{NO}_{3}\right)-\mathrm{N}$ content increased in organic (OF) and integrated $(\mathrm{HDF}+\mathrm{OF} \& \mathrm{HDF}+\mathrm{HOF})$ fertilizer plots, $\mathrm{CK}, \mathrm{RPK}$ and RPK $+\mathrm{NF}$ depicted a constant decrement in $\left(\mathrm{NO}_{3}\right)$-N content while RDF showed increased $\left(\mathrm{NO}_{3}\right)-\mathrm{N}$ content in third crop season (2017-18). The integrated fertilizer $(\mathrm{HDF}+\mathrm{OF})$ option favored a higher $\left(\mathrm{NO}_{3}\right)-\mathrm{N}$ contents at both soil profiles as compared to that in RDF option. That benefit (greater nitrate content) of inclusion of organic fertilizer (FYM) were, however more remarkable during terminal year (2018-19).

Table 9. Effects of different nutrient management options on the soil organic carbon (SOC) content $\left(\mathrm{g} \mathrm{kg}^{-1}\right)$ at soil depths of $0-15$ and $15-30 \mathrm{~cm}$ after 4 crop cycles.

\begin{tabular}{|c|c|c|c|c|c|c|c|c|}
\hline \multirow{2}{*}{ Treatment } & \multicolumn{4}{|c|}{ 0-15 cm Depth } & \multicolumn{4}{|c|}{ 15-30 cm Depth } \\
\hline & 2015-16 & 2016-17 & 2017-18 & 2018-19 & 2015-16 & 2016-17 & 2017-18 & 2018-19 \\
\hline CK & $4.8^{\mathrm{cA}}$ & $4.4^{\mathrm{c} A \mathrm{~B}}$ & $3.9^{\mathrm{cB}}$ & $3.3^{\mathrm{dC}}$ & $3.1^{\mathrm{cA}}$ & $2.9^{\mathrm{bA}}$ & $2.8^{\mathrm{eAB}}$ & $2.6^{\mathrm{dB}}$ \\
\hline RDF & $5.3^{\mathrm{abA}}$ & $5.1^{\mathrm{bA}}$ & $5.1^{\mathrm{cA}}$ & $5.3^{\mathrm{bA}}$ & $3.2^{\mathrm{aB}}$ & $3.3^{\mathrm{bB}}$ & $3.5^{\mathrm{bA}}$ & $3.6^{\mathrm{bA}}$ \\
\hline $\mathrm{OF}$ & $5.9^{\mathrm{aC}}$ & $6.5^{\mathrm{aBC}}$ & $7.1^{\mathrm{aB}}$ & $7.3^{\mathrm{aA}}$ & $3.3^{\mathrm{aC}}$ & $3.8^{\mathrm{aBC}}$ & $4.0^{\mathrm{aB}}$ & $4.3^{\mathrm{aA}}$ \\
\hline $\mathrm{HDF}+\mathrm{OF}$ & $5.8^{\mathrm{aC}}$ & $6.4^{\mathrm{aBC}}$ & $7.2^{\mathrm{aB}}$ & $7.5^{\mathrm{aA}}$ & $3.4^{\mathrm{aC}}$ & $3.8^{\mathrm{aBC}}$ & $4.1^{\mathrm{aA}}$ & $4.4^{\mathrm{aA}}$ \\
\hline $\mathrm{HDF}+\mathrm{HOF}$ & $5.6^{\mathrm{abC}}$ & $5.8^{\mathrm{aC}}$ & $6.3^{\mathrm{bB}}$ & $6.6^{\mathrm{aA}}$ & $3.1^{\mathrm{bC}}$ & $3.3^{\mathrm{bBC}}$ & $3.5^{\mathrm{bB}}$ & $3.8^{\mathrm{bA}}$ \\
\hline RPK & $4.9^{\mathrm{bcA}}$ & $4.6 b^{\mathrm{cB}}$ & $4.7^{\mathrm{dB}}$ & $5.0 \mathrm{~b}^{\mathrm{cA}}$ & $2.4^{\mathrm{cA}}$ & $2.2^{\mathrm{cB}}$ & $2.3^{\mathrm{cB}}$ & $2.5^{\mathrm{cA}}$ \\
\hline $\mathrm{RPK}+\mathrm{NF}$ & $5.2^{\mathrm{bA}}$ & $4.9^{\mathrm{cB}}$ & $4.6^{\mathrm{dC}}$ & $4.8^{\mathrm{cB}}$ & $2.5^{\mathrm{cA}}$ & $2.3^{\mathrm{cB}}$ & $2.2^{\mathrm{cB}}$ & $2.4^{\mathrm{cA}}$ \\
\hline
\end{tabular}

Values followed by different lower-case letter(s) within a column and upper-case letter(s) within a row are significant at $\mathrm{p} \leq 0.05$.

Table 10. Effects of different nutrient management options on the soil nitrogen ( $\left.\mathrm{NO}_{3}-\mathrm{N}\right)$ content (ppm) at soil depths of 0-15 and 15-30 cm after 4 crop cycles.

\begin{tabular}{|c|c|c|c|c|c|c|c|c|}
\hline \multirow{2}{*}{ Treatment } & \multicolumn{4}{|c|}{ 0-15 cm Depth } & \multicolumn{4}{|c|}{$15-30 \mathrm{~cm}$ Depth } \\
\hline & 2015-16 & 2016-17 & $2017-18$ & 2018-19 & 2015-16 & 2016-17 & 2017-18 & 2018-19 \\
\hline CK & $5.9^{\mathrm{cA}}$ & $4.6^{\mathrm{dAB}}$ & $3.9^{\mathrm{dB}}$ & $3.3^{\mathrm{dB}}$ & $5.2^{\mathrm{cA}}$ & $4.5^{\mathrm{dAB}}$ & $3.2^{\mathrm{dB}}$ & $3.0^{\mathrm{dB}}$ \\
\hline RDF & $6.2^{\mathrm{cA}}$ & $5.4^{\mathrm{cB}}$ & $5.6^{\mathrm{cB}}$ & $6.4^{\mathrm{cA}}$ & $5.6^{\mathrm{cB}}$ & $6.2^{\mathrm{cB}}$ & $6.6^{\mathrm{cB}}$ & $7.2^{\mathrm{cA}}$ \\
\hline $\mathrm{OF}$ & $9.8^{\mathrm{bB}}$ & $11.3^{\mathrm{aA}}$ & $11.9^{\mathrm{aA}}$ & $12.6^{\mathrm{aA}}$ & $7.8^{\mathrm{bB}}$ & $8.8^{\mathrm{bAB}}$ & $9.6^{\mathrm{bA}}$ & $10.8^{\mathrm{bA}}$ \\
\hline $\mathrm{HDF}+\mathrm{OF}$ & $12.4^{\mathrm{aB}}$ & $13.5^{\mathrm{aA}}$ & $14.1^{\mathrm{aA}}$ & $14.3^{\mathrm{aA}}$ & $10.1^{\mathrm{aB}}$ & $11.4^{\mathrm{aAB}}$ & $12.4^{\mathrm{aAB}}$ & $13.9^{\mathrm{aA}}$ \\
\hline $\mathrm{HDF}+\mathrm{HOF}$ & $7.5^{\mathrm{bcB}}$ & $7.8^{\mathrm{bB}}$ & $8.2^{\mathrm{bA}}$ & $8.3^{\mathrm{bA}}$ & $6.2^{\mathrm{cC}}$ & $7.0^{\mathrm{bB}}$ & $7.6^{\mathrm{bB}}$ & $8.5^{\mathrm{cA}}$ \\
\hline RPK & $6.0^{\mathrm{cA}}$ & $5.2 \mathrm{c}^{\mathrm{AB}}$ & $4.8^{\mathrm{cB}}$ & $4 c^{\mathrm{dC}}$ & $5.1^{\mathrm{cA}}$ & $4.6^{\mathrm{dAB}}$ & $3.3^{\mathrm{dB}}$ & $3.0^{\mathrm{dB}}$ \\
\hline $\mathrm{RPK}+\mathrm{NF}$ & $6.2^{\mathrm{cA}}$ & $5.3^{\mathrm{cB}}$ & $5.1^{\mathrm{cB}}$ & $4.9^{\mathrm{cB}}$ & $5.6^{\mathrm{cB}}$ & $6.0^{\mathrm{cB}}$ & $6.3^{\mathrm{cA}}$ & $6.8^{\mathrm{cA}}$ \\
\hline
\end{tabular}

Values followed by different lower-case letter(s) within a column and upper-case letter(s) within a row are significant at $\mathrm{p} \leq 0.05$.

The nutrient management options, increased $\left(\mathrm{NH}_{4}\right)-\mathrm{N}$ content as compared to RPK and $\mathrm{RK}+\mathrm{NF}$ in the surface soil layer $(0-15 \mathrm{~cm}$ depth); the magnitude of such increases were significantly higher under $\mathrm{HDF}+\mathrm{OF}$, followed by $\mathrm{OF}, \mathrm{HDF}+\mathrm{HOF}, \mathrm{RDK}$ and $\mathrm{CK}$ as presented in Table 11. Compared with the initial $\left(\mathrm{NH}_{4}\right)-\mathrm{N}$ content (11.5 $\pm 0.04 \mathrm{ppm}), \mathrm{RDF}$ and all other fertilizer options had $6-103.4 \%$ higher $\left(\mathrm{NH}_{4}\right)-\mathrm{N}$ contents in the surface soil layer during 2015-16. A similar pattern of increase in $\left(\mathrm{NH}_{4}\right)-\mathrm{N}$ content as the consequence of different fertilizer options was also observed after crop harvested in later years.

Soil available $P$ content. The available $P$ contents of the surface soil $(0-15 \mathrm{~cm}$ depth) were increased compared with the initial content $\left(8.8 \pm 0.07 \mathrm{mgkg}^{-1}\right)$ under different fertilizer option with passage of time. After the end of this long-term study (2018-19), the maximum available in the surface soil was observed under $\mathrm{HDF}+\mathrm{OF}(29.6 \mathrm{mg}$ $\left.\mathrm{kg}^{-1}\right)$, followed by RDF $\left(22.4 \mathrm{mg} \mathrm{kg}^{-1}\right)$, whereas a relatively lower $\mathrm{P}$ content $\left(20.4 \mathrm{mg} \mathrm{kg}^{-1}\right)$ was measured under HDF+HOF option. The results of fertilizer options were relatively smaller in sub-surface soil layer (15-30 $\mathrm{cm}$ depth). Nonetheless, the maximum increment in $\mathrm{P}$ content over the initial content $\left(6.5 \pm 0.06 \mathrm{mgkg}^{-1}\right)$ in the sub-surface soil was characterized by $125 \%$ during terminal year (2018-19). Relatively smaller P accumulations over the initial content was observed under OF (12\%). On the other hand, a $23 \%$ decline in $\mathrm{P}$ content over initial content was noticed under CK option.

Soil exchangeable $\mathbf{K}$ content. Over the years of experiment, soil exchangeable $\mathrm{K}$ contents consistently increased under $\mathrm{OF}, \mathrm{HDF}+\mathrm{OF}$ and $\mathrm{HDF}+\mathrm{HOF}$ fertilizer options containing FYM. At soil depths 0-15 and 15-30 
$\mathrm{cm}$, the highest $\mathrm{K}$ contents (125.4 and $96.2 \mathrm{mgkg}^{-1}$, respectively) were measured under $\mathrm{HDF}+\mathrm{OF}$ and these were on par with the values under all other fertilizer options during last year (2018-19). When compared with the initial $\mathrm{K}$ contents $\left(76.2 \pm 1.22\right.$ and $67.6 \pm 2.38 \mathrm{mg} \mathrm{kg}^{-1}$ at 0-15 and 15-30 $\mathrm{cm}$ soil depths, respectively), the $\mathrm{K}$ contents of the soil at the end of experiment increased $45.3 \%, 64.6 \%$ and $29.1 \%$ at $0-15 \mathrm{~cm}$ depth and by $30.1 \%$,
$26.2 \%$ and $13.4 \%$ at the $15-30 \mathrm{~cm}$ depth under $\mathrm{OF}$, $\mathrm{HDF}+\mathrm{OF}$ and $\mathrm{HDF}+\mathrm{HOF}$, respectively as presented in the Table 13. On the contrary, a consistent depletion of $\mathrm{K}$ contents was measured in the RDF, RPK, RPK+NF and $\mathrm{CK}$, whereas it remained significantly lower $(p \leq 0.05)$ than that in all other treatments during all crop year at both soil depths $(0-15$ and $15-30 \mathrm{~cm})$.

Table 11. Effects of different nutrient management options on the soil nitrogen ( $\left.\mathrm{NH}_{4}-\mathrm{N}\right)$ content (ppm) at soil depths of $0-15$ and $15-30 \mathrm{~cm}$ after 4 crop cycles.

\begin{tabular}{ccccccccc}
\hline \multirow{2}{*}{ Treatment } & \multicolumn{4}{c}{$\mathbf{0 - 1 5} \mathbf{~ c m}$ Depth } & \multicolumn{3}{c}{$\mathbf{1 5 - 3 0}$ cm Depth } \\
\cline { 2 - 8 } & $\mathbf{2 0 1 5 - 1 6}$ & $\mathbf{2 0 1 6 - 1 7}$ & $\mathbf{2 0 1 7 - 1 8}$ & $\mathbf{2 0 1 8 - 1 9}$ & $\mathbf{2 0 1 5 - 1 6}$ & $\mathbf{2 0 1 6 - 1 7}$ & $\mathbf{2 0 1 7 - 1 8}$ & $\mathbf{2 0 1 8 - 1 9}$ \\
\hline CK & $9.7^{\mathrm{cB}}$ & $11.2^{\mathrm{dA}}$ & $11.8^{\mathrm{dA}}$ & $11.7^{\mathrm{dA}}$ & $9.6^{\mathrm{cB}}$ & $10.3^{\mathrm{cB}}$ & $11.1^{\mathrm{cA}}$ & $11.5^{\mathrm{cdA}}$ \\
RDF & $12.2^{\mathrm{bcB}}$ & $12.6^{\mathrm{dB}}$ & $13.6^{\mathrm{dA}}$ & $15.7^{\mathrm{cA}}$ & $9.2^{\mathrm{cB}}$ & $10.5^{\mathrm{cAB}}$ & $11.1^{\mathrm{cAB}}$ & $13.2^{\mathrm{cA}}$ \\
OF & $17.5^{\mathrm{bB}}$ & $18.6^{\mathrm{bB}}$ & $21.8^{\mathrm{bA}}$ & $22.9^{\mathrm{bA}}$ & $16.6^{\mathrm{abAB}}$ & $15.2^{\mathrm{abB}}$ & $16.1^{\mathrm{abAB}}$ & $18.4^{\mathrm{bA}}$ \\
HDF+OF & $23.4^{\mathrm{aB}}$ & $24.7^{\mathrm{aB}}$ & $28.4^{\mathrm{aA}}$ & $30.5^{\mathrm{aA}}$ & $21.0^{\mathrm{aB}}$ & $20.2^{\mathrm{aB}}$ & $21.4^{\mathrm{aB}}$ & $24.8^{\mathrm{aA}}$ \\
HDF+HOF & $14.5^{\mathrm{bcB}}$ & $15.3^{\mathrm{cB}}$ & $17.4^{\mathrm{cA}}$ & $19.0^{\mathrm{bA}}$ & $12.6^{\mathrm{bB}}$ & $12.5^{\mathrm{bB}}$ & $13.3^{\mathrm{bAB}}$ & $15.5^{\mathrm{bcA}}$ \\
RPK & $6.6^{\mathrm{dA}}$ & $6.0^{\mathrm{eAB}}$ & $5.7^{\mathrm{fAB}}$ & $5.2^{\mathrm{eB}}$ & $6.0^{\mathrm{dA}}$ & $5.6^{\mathrm{dA}}$ & $4.9^{\mathrm{dB}}$ & $4.7^{\mathrm{eB}}$ \\
RPK+NF & $7.4^{\mathrm{dA}}$ & $6.5^{\mathrm{eB}}$ & $7.2^{\mathrm{eA}}$ & $6.1^{\mathrm{eB}}$ & $6.8^{\mathrm{dB}}$ & $7.2^{\mathrm{dAB}}$ & $7.5^{\mathrm{cdAB}}$ & $8.0^{\mathrm{dA}}$ \\
\hline
\end{tabular}

Values followed by different lower-case letter(s) within a column and upper-case letter(s) within a row are significant at $\mathrm{p} \leq 0.05$.

Table 12. Effects of different nutrient management options on the soil phosphorus (P) content (mg kg-1) at soil depths of $0-15$ and $15-30 \mathrm{~cm}$ after 4 crop cycles.

\begin{tabular}{|c|c|c|c|c|c|c|c|c|}
\hline \multirow{2}{*}{ Treatment } & \multicolumn{4}{|c|}{ 0-15 cm Depth } & \multicolumn{4}{|c|}{ 15-30 cm Depth } \\
\hline & 2015-16 & 2016-17 & 2017-18 & 2018-19 & 2015-16 & 2016-17 & 2017-18 & 2018-19 \\
\hline CK & $8.5^{\mathrm{dA}}$ & $8.1^{\mathrm{dAB}}$ & $7.6^{\mathrm{dAB}}$ & $7.4^{\mathrm{dB}}$ & $6.1^{\mathrm{cA}}$ & $5.4^{\mathrm{dB}}$ & $5.4^{\mathrm{dB}}$ & $4.4^{\mathrm{dC}}$ \\
\hline $\mathrm{RDF}$ & $13.5^{\mathrm{bD}}$ & $16.4^{\mathrm{bC}}$ & $20.2^{\mathrm{bB}}$ & $22.4^{\mathrm{bA}}$ & $6.8^{\mathrm{bD}}$ & $9.0^{\mathrm{bC}}$ & $11.4^{\mathrm{aB}}$ & $14.1^{\mathrm{aA}}$ \\
\hline $\mathrm{OF}$ & $13.2^{\mathrm{bD}}$ & $14.6^{\mathrm{cC}}$ & $17.7^{\mathrm{cB}}$ & $18.7^{\mathrm{cA}}$ & $7 b^{\mathrm{AB}}$ & $6.9^{\mathrm{cB}}$ & $7.4^{\mathrm{cA}}$ & $7.3^{\mathrm{cAB}}$ \\
\hline $\mathrm{HDF}+\mathrm{OF}$ & $19.6^{\mathrm{aB}}$ & $22.5^{\mathrm{aB}}$ & $27.5^{\mathrm{aA}}$ & $29.6^{\mathrm{aA}}$ & $10.1^{\mathrm{aB}}$ & $11.1^{\mathrm{aAB}}$ & $12.8^{\mathrm{aAB}}$ & $14.0^{\mathrm{aA}}$ \\
\hline $\mathrm{HDF}+\mathrm{HOF}$ & $13.2^{\mathrm{bC}}$ & $15.3^{\mathrm{cB}}$ & $18.8^{\mathrm{bAB}}$ & $20.4^{\mathrm{bA}}$ & $6.7^{\mathrm{bC}}$ & $7.8^{\mathrm{cB}}$ & $9.2^{\mathrm{bAB}}$ & $10.6^{\mathrm{bA}}$ \\
\hline RPK & $12.5^{\mathrm{cC}}$ & $16.3^{\mathrm{bB}}$ & $18.9^{\mathrm{bAB}}$ & $21.6^{\mathrm{bA}}$ & $6.9^{\mathrm{bC}}$ & $9.3^{\mathrm{bC}}$ & $11.5^{\mathrm{aB}}$ & $14.6^{\mathrm{aA}}$ \\
\hline $\mathrm{RPK}+\mathrm{NF}$ & $12.4^{\mathrm{cC}}$ & $15.3^{\mathrm{cB}}$ & $19.1^{\mathrm{bAB}}$ & $21.4^{\mathrm{bA}}$ & $6.6^{\mathrm{bD}}$ & $8.7^{\mathrm{bC}}$ & $11.2^{\mathrm{aB}}$ & $13.9^{\mathrm{aA}}$ \\
\hline
\end{tabular}

Values followed by different lower-case letter(s) within a column and upper-case letter(s) within a row are significant at $\mathrm{p} \leq 0.05$.

Soil available $\mathbf{S}$ content. At terminal stage of experiment, the soil $\mathrm{S}$ contents increased considerably over the initial content $\left(14.7 \pm 1.22\right.$ and $\left.9.8 \pm 0.35 \mathrm{mgkg}^{-1}\right)$ at soil profile depths $0-15$ and $15-30 \mathrm{~cm}$ under fertilizer options containing FYM as given in Table 14. Compared with initial S status, $\mathrm{HDF}+\mathrm{OF}$ had a $136.7 \%$ and $35.37 \%$ higher available $S$ contents at the $0-15$ and $15-30 \mathrm{~cm}$ profile depths during 2018-19. The increased S contents under $\mathrm{OF}$ and $\mathrm{HDF}+\mathrm{HOF}$ were $112.2 \%$ and $20.4 \%$, $53.7 \%$ and $40.8 \%$, respectively during the terminal years. On the other hand, RDF, RPK and RPK+NF could not prevent a decline in $\mathrm{S}$ content, as depletions of $47 \%$ and $61 \%, 50.4 \%$ and $64.6 \%, 48.3 \%$ and $62.3 \%$ over the initial soil S content were noticed at soil depths of $0-15$ and 15$30 \mathrm{~cm}$ depths, respectively, during 2018-19. A depletion of available $\mathrm{S}$ over the initial $\mathrm{S}$ content was also noticed in the control, but the magnitude was smaller than that under the RDF, RPK and RPK+NF plots.
Soil DTPA-Zn content. The DTPA-Zn content varied among the different nutrient management options, soil profile depths and years of experiment as shown in Table 15. Whereas DTPA-Zn content increased significantly over the initial content $\left(0.6 \pm 0.07\right.$ and $\left.0.48 \pm 0.05 \mathrm{mg} \mathrm{kg}^{-1}\right)$ in the 0-15 and $15-30 \mathrm{~cm}$ soil depths, respectively, under $\mathrm{RDF}, \mathrm{HDF}+\mathrm{OF}, \mathrm{HDF}+\mathrm{HOF}, \mathrm{RPK}$ and $\mathrm{RPK}+\mathrm{NF}$ options. A continuous decline in DTPA-Zn was noticed under OF and $\mathrm{CK}$ over the year at both soil profile depths. At the end of experiment, an additional $\mathrm{Zn}$ accumulation of $0.29,0.23,0.03,0.05$ and $0.25 \mathrm{mg} \mathrm{kg}^{-1}$ at $0-15 \mathrm{~cm}$ and $0.16,0.19,0.02,0.12$ and $0.14 \mathrm{mg} \mathrm{kg}^{-1}$ at the $15-30 \mathrm{~cm}$ soil profile depth were noticed over its initial status under $\mathrm{RDF}$ and in all other fertilizer options, respectively. conversely, declines of 0.21 and $0.12 \mathrm{mg} \mathrm{kg}-1,0.22$ and $0.12 \mathrm{mg} \mathrm{kg}-1$ in DTPA-Zn were noticed under CK and OF treatment at the $0-15$ and $15-30 \mathrm{~cm}$ profile depths, respectively, during 2018-19. 
Table 13. Effects of different nutrient management options on the soil potassium (K) content ( $\mathrm{g} \mathrm{kg}-1)$ at soil depths of $0-15$ and $15-30 \mathrm{~cm}$ after 4 crop cycles.

\begin{tabular}{ccccccccc}
\hline \multirow{2}{*}{ Treatment } & \multicolumn{9}{c}{$\mathbf{0 - 1 5}$ cm Depth } & \multicolumn{4}{c}{$\mathbf{1 5 - 3 0}$ cm Depth } \\
\cline { 2 - 9 } & $\mathbf{2 0 1 5 - 1 6}$ & $\mathbf{2 0 1 6 - 1 7}$ & $\mathbf{2 0 1 7 - 1 8}$ & $\mathbf{2 0 1 8 - 1 9}$ & $\mathbf{2 0 1 5 - 1 6}$ & $\mathbf{2 0 1 6 - 1 7}$ & $\mathbf{2 0 1 7 - 1 8}$ & $\mathbf{2 0 1 8 - 1 9}$ \\
\hline CK & $70.1^{\mathrm{bcA}}$ & $68.3^{\mathrm{bcA}}$ & $65.6^{\mathrm{bcA}}$ & $62.7^{\mathrm{bcA}}$ & $65.5^{\mathrm{bA}}$ & $63.4^{\mathrm{cAB}}$ & $61.3^{\mathrm{cB}}$ & $59.3^{\mathrm{cB}}$ \\
RDF & $71.5^{\mathrm{bcA}}$ & $66.3^{\mathrm{bcA}}$ & $62.3^{\mathrm{bcA}}$ & $60.0^{\mathrm{bcA}}$ & $64.7^{\mathrm{bA}}$ & $61.1^{\mathrm{dAB}}$ & $58.8^{\mathrm{cAB}}$ & $55.1^{\mathrm{cdB}}$ \\
OF & $88.4^{\mathrm{abC}}$ & $95.7^{\mathrm{abB}}$ & $100.5^{\mathrm{abB}}$ & $110.7^{\mathrm{bcA}}$ & $73.0^{\mathrm{aC}}$ & $80.9^{\mathrm{bB}}$ & $85.8^{\mathrm{aB}}$ & $91.5^{\mathrm{aA}}$ \\
HDF+OF & $99.5^{\mathrm{aC}}$ & $107.9^{\mathrm{aB}}$ & $113.2^{\mathrm{aB}}$ & $125.4^{\mathrm{aA}}$ & $76.9^{\mathrm{aC}}$ & $85.4^{\mathrm{aB}}$ & $90.5^{\mathrm{aB}}$ & $96.2^{\mathrm{aA}}$ \\
HDF+HOF & $76.4^{\mathrm{bC}}$ & $84.3^{\mathrm{bB}}$ & $93.5^{\mathrm{bAB}}$ & $98.4^{\mathrm{bA}}$ & $58.6^{\mathrm{CC}}$ & $69.5 \mathrm{~b}^{\mathrm{cBC}}$ & $77.6^{\mathrm{bB}}$ & $86.4^{\mathrm{bA}}$ \\
RPK & $68.5^{\mathrm{cA}}$ & $64.7^{\mathrm{dA}}$ & $59.6^{\mathrm{dB}}$ & $58.3^{\mathrm{dB}}$ & $63.1^{\mathrm{bcA}}$ & $59.8^{\mathrm{cdB}}$ & $57.3^{\mathrm{dB}}$ & $54.6^{\mathrm{dC}}$ \\
RPK+NF & $69.8^{\mathrm{bcA}}$ & $65.2^{\mathrm{cA}}$ & $60.6^{\mathrm{cA}}$ & $58.8^{\mathrm{cA}}$ & $64.2^{\mathrm{bA}}$ & $60.5 \mathrm{c}^{\mathrm{dAB}}$ & $57.9^{\mathrm{cdAB}}$ & $54.8^{\mathrm{cdB}}$ \\
\hline
\end{tabular}

Values followed by different lower-case letter(s) within a column and upper-case letter(s) within a row are significant at $\mathrm{p} \leq 0.05$.

Table 14. Effects of different nutrient management options on the soil Sulphur (S) content (mg kg-1) at soil depths of $0-15$ and $15-30 \mathrm{~cm}$ after 4 crop cycles.

\begin{tabular}{|c|c|c|c|c|c|c|c|c|}
\hline \multirow{2}{*}{ Treatment } & \multicolumn{4}{|c|}{ 0-15 cm Depth } & \multicolumn{4}{|c|}{$15-30 \mathrm{~cm}$ Depth } \\
\hline & 2015-16 & 2016-17 & $2017-18$ & 2018-19 & 2015-16 & 2016-17 & 2017-18 & 2018-19 \\
\hline CK & $10.5^{\mathrm{cA}}$ & $9.9^{\mathrm{cAB}}$ & $9.1^{\mathrm{cBC}}$ & $8.2^{\mathrm{cC}}$ & $7.6^{\mathrm{cA}}$ & $7.3^{\mathrm{cA}}$ & $7.4^{\mathrm{cA}}$ & $7.0^{\mathrm{cA}}$ \\
\hline $\mathrm{RDF}$ & $10.4^{\mathrm{cA}}$ & $9.3^{\mathrm{cAB}}$ & $8.6^{\mathrm{cBC}}$ & $7.8^{\mathrm{cC}}$ & $7.2^{\mathrm{cA}}$ & $6.6^{\mathrm{cAB}}$ & $6.4^{\mathrm{cB}}$ & $5.8^{\mathrm{cB}}$ \\
\hline OF & $18.7^{\mathrm{aD}}$ & $22.6^{\mathrm{bC}}$ & $28.8^{\mathrm{aB}}$ & $31.2^{\mathrm{aA}}$ & $12^{\mathrm{aD}}$ & $14.2^{\mathrm{aC}}$ & $15.5^{\mathrm{aB}}$ & $17.7^{\mathrm{aA}}$ \\
\hline $\mathrm{HDF}+\mathrm{OF}$ & $22.1^{\mathrm{aC}}$ & $28.3^{\mathrm{aB}}$ & $30.7^{\mathrm{aB}}$ & $34.8^{\mathrm{aA}}$ & $13.7^{\mathrm{aC}}$ & $15.0^{\mathrm{aB}}$ & $17.2^{\mathrm{aB}}$ & $19.9^{\mathrm{aA}}$ \\
\hline $\mathrm{HDF}+\mathrm{HOF}$ & $14.6^{\mathrm{bB}}$ & $17.3^{\mathrm{bAB}}$ & $21.5^{\mathrm{bA}}$ & $22.6^{\mathrm{bA}}$ & $9.4^{\mathrm{bC}}$ & $11.1^{\mathrm{bB}}$ & $12.1^{\mathrm{bB}}$ & $13.8^{\mathrm{bA}}$ \\
\hline RPK & $10.2^{\mathrm{cA}}$ & $9.3^{\mathrm{cB}}$ & $8.6^{\mathrm{cBC}}$ & $7.3^{\mathrm{cC}}$ & $7.1^{\mathrm{cA}}$ & $6.8^{\mathrm{cA}}$ & $6.0^{\mathrm{cAB}}$ & $5.2^{\mathrm{dB}}$ \\
\hline $\mathrm{RPK}+\mathrm{NF}$ & $10.1^{\mathrm{cA}}$ & $9.1^{\mathrm{cAB}}$ & $8.4^{\mathrm{cB}}$ & $7.6^{\mathrm{cC}}$ & $7.0^{\mathrm{cA}}$ & $6.5^{\mathrm{cAB}}$ & $6.2^{\mathrm{cB}}$ & $5.5^{\mathrm{dB}}$ \\
\hline
\end{tabular}

Values followed by different lower-case letter(s) within a column and upper-case letter(s) within a row are significant at $\mathrm{p} \leq 0.05$.

Table 15. Effects of different nutrient management options on the soil zinc (DTPA-Zn) content (mg kg-1) at soil depths of $0-15$ and $15-30 \mathrm{~cm}$ after 4 crop cycles.

\begin{tabular}{ccccccccc}
\hline \multirow{2}{*}{ Treatment } & \multicolumn{9}{c}{$\mathbf{0 - 1 5} \mathbf{c m}$ Depth } & \multicolumn{4}{c}{$\mathbf{1 5 - 3 0}$ cm Depth } \\
\cline { 2 - 8 } & $\mathbf{2 0 1 5 - 1 6}$ & $\mathbf{2 0 1 6 - 1 7}$ & $\mathbf{2 0 1 7 - 1 8}$ & $\mathbf{2 0 1 8 - 1 9}$ & $\mathbf{2 0 1 5 - 1 6}$ & $\mathbf{2 0 1 6 - 1 7}$ & $\mathbf{2 0 1 7 - 1 8}$ & $\mathbf{2 0 1 8 - 1 9}$ \\
\hline CK & $0.50^{\mathrm{dA}}$ & $0.45^{\mathrm{dAB}}$ & $0.42^{\mathrm{dBC}}$ & $0.39^{\mathrm{dC}}$ & $0.43^{\mathrm{cA}}$ & $0.41^{\mathrm{cA}}$ & $0.39^{\mathrm{cB}}$ & $0.36^{\mathrm{cB}}$ \\
RDF & $0.69^{\mathrm{bB}}$ & $0.72^{\mathrm{bB}}$ & $0.85^{\mathrm{aA}}$ & $0.89^{\mathrm{aA}}$ & $0.53^{\mathrm{bB}}$ & $0.56^{\mathrm{bB}}$ & $0.62^{\mathrm{aA}}$ & $0.64^{\mathrm{aA}}$ \\
OF & $0.53^{\mathrm{cA}}$ & $0.46^{\mathrm{dB}}$ & $0.41^{\mathrm{dBC}}$ & $0.38^{\mathrm{dC}}$ & $0.44^{\mathrm{cA}}$ & $0.42^{\mathrm{cA}}$ & $0.37^{\mathrm{cB}}$ & $0.36^{\mathrm{cB}}$ \\
HDF+OF & $0.86^{\mathrm{aA}}$ & $0.80^{\mathrm{aB}}$ & $0.81^{\mathrm{aB}}$ & $0.83^{\mathrm{bA}}$ & $0.68^{\mathrm{aA}}$ & $0.69^{\mathrm{aA}}$ & $0.67^{\mathrm{aA}}$ & $0.67^{\mathrm{aA}}$ \\
HDF+HOF & $0.60^{\mathrm{bcB}}$ & $0.58^{\mathrm{cB}}$ & $0.62^{\mathrm{cA}}$ & $0.63^{\mathrm{cA}}$ & $0.48^{\mathrm{bcA}}$ & $0.49^{\mathrm{bcA}}$ & $0.50^{\mathrm{bA}}$ & $0.50^{\mathrm{bA}}$ \\
RPK & $0.55^{\mathrm{bcB}}$ & $0.58^{\mathrm{cB}}$ & $0.61^{\mathrm{cA}}$ & $0.65^{\mathrm{cA}}$ & $0.46^{\mathrm{bcC}}$ & $0.50^{\mathrm{bcB}}$ & $0.53^{\mathrm{abB}}$ & $0.60^{\mathrm{aA}}$ \\
RPK+NF & $0.67^{\mathrm{bC}}$ & $0.69^{\mathrm{bC}}$ & $0.77^{\mathrm{bB}}$ & $0.85^{\mathrm{aA}}$ & $0.50^{\mathrm{bC}}$ & $0.53^{\mathrm{bC}}$ & $0.58^{\mathrm{abB}}$ & $0.62^{\mathrm{aA}}$ \\
\hline
\end{tabular}

Values followed by different lower-case letter(s) within a column and upper-case letter(s) within a row are significant at $\mathrm{p} \leq 0.05$.

\section{DISCUSSION}

According to the obtained results, different fertilizer options significantly affected plant morphological growth and yield characteristics during the entire experiment. Soil physical health improved season by season in plots fertilized with integrated organic and inorganic fertilizer (FYM) and gave better-developed plants, consequently better seed yield after every season. Inorganic fertilizers (NPK) produced better plant development and seed yield during initial years of experiment, but continuous use in later years suppressed plant physiological growth, susceptible to disease attack and resulted in low seed yield. The results can be justified by Lee, (2010) who revealed that continuous application of NPK develop unfavorable plant-soil interaction, inhibits plant vegetative growth and results in less crop yield. The optimum results were found in plot fertilized with mixed organic and inorganic $(\mathrm{HDF}+\mathrm{OF})$ option than all other fertilizer options. Therefore, it would be suggested that integrated fertilizer application is suitable for good plant vegetative growth, resistant to disease and yield characteristics. The results were in line with Mukhtar et al., (2011), who reported that higher level of nitrogen significantly increased plant height. He also reported parallel results in mustard. The results also 
revealed the influence of long-term various fertigation options on yield characteristics.

The fresh biomass and glucosinolates contents were significantly higher in eruca plant fed with integrated organic and integrated fertilizer options than inorganic options (Table 7). These results are agreed with (De Pacale et al., 2007). The application rates of $\mathrm{N}$ and $\mathrm{K}$ significantly modify some bioactive substance in eruca plants. The high rate of $\mathrm{N}$ increase plant fresh matter, at the same time, causing a decrease in L-ascorbic acid and glucosinolates content. Omirou et al., 2012 revealed that the glucosinolates content in eruca leaves modified significantly by the rate of $\mathrm{N}$ growth stage. Moreover, different glucosinolates showed a different response to an increase in the rate of $\mathrm{N}$ and $\mathrm{K}$ (Kim et al., 2006; Omirou et al., 2012). Glucosinolates content under optimal plant growth look more stable. In this study, plants that received organic fertilizer were characterized by higher fresh matter and other bioactive substances compared to all other inorganic fertilizer throughout the experiment. Other studies conducted also showed that sulfate $\mathrm{S}$ application (FYM) to canola increased oil concentration and protein content in seed on S-deficient soils (Malhi and Gill, 2002). Acikgoz (2011) marked Brassica vegetables by a high value of L-ascorbic acid and protein, which are the main determinants for nutritional value. This study results can be compared with values observed in cabbage plants (Acikgoz, 2011), partially in mustard greens (Ng et al., 2012) and green leafy vegetables ( $\mathrm{Ng}$ et al., 2012; Yadav et al., 2013). The chlorophyll content in leafy vegetables varies from $0.04-2.70 \mathrm{mg}$ g-1 of fresh matter (Kamga et al., 2013; Mitic et al., 2013; Vivek et al., 2013). Ng et al., (2012) determined similar results of flavonoids for mustard greens. The glucosinolates content in leaves of genera Brassica, Degenia and Eruca can range 9.9-31.4 $\mu \mathrm{mol}$ g-1 of dry matter (De Pacale et al., 2007; De Nicola et al., 2011; Omirou et al., 2012) and associated with $\mathrm{N}$ content applied (Omirou et al., 2012).

The high dietary fibre content $13.39-16.65 \%$ of dry matter, exceeded the amounts found for other leafy and Brassica vegetables should be stressed (Januškevičius et al., 2012). Compared to mustard green, eruca had higher percentages of dry matter, fat, fibre, and ash but a lower concentration of carbohydrates ( $\mathrm{Ng}$ et al., 2012). The above differences in values were probably due to genetic and nutrients applied that modified the nutritional values of eruca plants. Eruca belongs to leafy vegetables, but also to the group of Brassica vegetables which primarily accumulate large amounts of mineral nutrients, protein content and vitamins (Acikgoz, 2011; Januškevičius et al., 2012). Previous studies proved that the eruca leaves contain more protein than leaves of other species and other Brassica vegetable species (NurzyńskaWierdak, 2015). These nutritional values were comparable to the values of some leafy vegetables (Iheanacho and Udebuani, 2009; Onwordi et al., 2009).
Eruca proved to be particularly rich in mineral nutrients. The ash content is an indicator of mineral content, determined in this experiment ranged 18.25 \pm 0.23 $20.77 \pm 0.32 \%$ of dry matter and exceeded 6.3 and 2.5 times the mineral content observed in lettuce and cabbage respectively (Januškevičius et al., 2012). NurzyńskaWierdak, (2009) revealed that an increase in $\mathrm{K}$ content decrease in the concentration of total sugars, calcium, chlorine, and potassium contents in eruca leaves.

Leafy vegetables can be a good source of energy (Kanchan and Veenapani, 2011; Ng et al., 2012) and $100 \mathrm{~g}$ of the leafy vegetable can provide energy from 601.8 to $1287.9 \mathrm{~kJ}$ (Patricia et al., 2014). The energetic values calculated during all the seasons of this study were within the above-mentioned range and agreed with the general finding that vegetable has comparatively low energetic values (Lintas, 1992; Patricia et al., 2014).

The high perishability of eruca leaves is a sign of its high respiration rate (Koukounaras et al., 2007) and is further controlled through storage temperature, representing that storage temperature is a key factor in the shelf life of eruca leaves. In this study, respiration rates of leaves stored at $10^{\circ} \mathrm{C}$ were 2 times higher than those stored at $0^{\circ} \mathrm{C}$ which agreed with Toivonen and Brummell, (2008) who reported 2-4 times to increase in respiration rates when temperature increased from 1 to $12^{\circ} \mathrm{C}$. During all seasons, the initial rise in $\mathrm{CO} 2$ followed by a plateau at later storage days and an inverse relationship between $\mathrm{O}_{2}$ and $\mathrm{CO}_{2}$ levels is also in line with (Koukounaras et al., 2007). The relatively constant chlorophyll levels throughout the storage period of 0 and $5^{\circ} \mathrm{C}$, showed that senescence was effectively delayed at these two temperatures. This is consistent with a reduction in respiration rate at lower temperatures since senescence is an energy-requiring process (Lim et al., 2007). The other factor affecting senescence progression is $\mathrm{O}_{2}$ level: by 6 days at the two higher temperatures, $\mathrm{O}_{2}$ had dropped to levels $\leq 5 \%$ which inhibits natural senescence. The similar effects were observed by (Løkke et al., 2012) leading Mg loss from chlorophyll resulting in an olive-brown color instead of yellowish (Toivonen and Brummell, 2008).

Long-term use of RDF increased soil bulk density which are main constraints for sustainable crop productivity. On the other hand, a decrease in soil bulk density, particularly subsoil surface (15-30 and 30-45 cm depths) under integrated fertilizer options, consequent the inclusion of FYM increased SOC and improved soil porosity, in turn, facilitating better root development and growth. The addition of FYM prevented closer packing of soil particles which improved soil aggregation and aeration. The other soil nutrients were also improved in integrated fertilizer options which resulted better soil physical health compared with all other chemical fertilizers. 
Conclusion: The temporal results of the long-term soil feralization study highlighted the reality that the sustainable high crop productivity under intensive cropping system can't be achieved through a single nutrient source be it chemical or organic fertilizer. On the other hand, use of integrated fertilizer options proved better in term of soil health, plant development and crop productivity. The addition of farmyard manure (FYM) as an organic fertilizer to Taramira (Eruca sativa L.) had an added benefit concerning chemical (RDF) fertilizer alone, as was obvious from the improvement in plant development characteristics, crop yield and soil physical health.

Author Contributions: Conceptualization, Design and Development, N.R.S.; Data collection, N.R.S. and A.M.; Formal Analysis, N.R.S.; Investigation and Methodology, N.R.S., A.M.M. and W.Z.; Supervision, U.M. and S.Y.; Visualization, N.R.S. and U.M.; Writing - original draft, N.R.S.; Writing review, S.Y., Y.M. and U.M.; Write-up editing, N.R.S.

Funding: This research received no external funding

Conflicts of Interest: The authors declared no conflict of interest.

Acknowledgments: The authors would like to acknowledge to all the services and technical support of Koont research Farm, Chakwal Road, PMAS-Arid Agriculture University Rawalpindi and Department of Agriculture, Biological, Environment and Energy Engineering, College of Engineering, Northeast Agricultural University, Harbin provided during research work setting, instrumentation, data collection and writeup compilation.

\section{REFERENCES}

AOAC (1990). Official Methods of Analysis. 15 $5^{\text {th }}$ Ed. Association of Official Analytical Chemists; Washington (USA).

AOAC (1980). Official Methods of Analysis, $13^{\text {th }}$ edn., Association of Official Agricultural Chemists, Washington, USA.

Acikgoz, F.E. (2011). Mineral, vitamin C and crude protein contents in kale (Brassica oleraceae var. acephala) at different harvesting stages. Afr. J. Biotech,10: 17170-17174.

Blake, G.R. and K.H. Hartge (1986). Bulk density. In Methods of Soil Analysis, Part 1; Klute, A., Ed.; Physical and Mineralogical Properties, Monograph 9; ASA: Madison, WI, USA, 363376.

Bremner, J.M. and D.R. Keeney (1965). Steam distillation methods for determination of ammonium, nitrate and nitrite. Anal. Chem. Acta, 32: 485-495.

Bowles, T.M., V. Acosta-Martinez, F. Calderon and L.E. Jackson (2014). Soil enzyme activities, microbial communities, and carbon and nitrogen availability in organic agroecosystems across an intensively managed agricultural landscape. Soil Biol. Biochem, 68: 252-262.

De Pascale, S., A. Maggioa, R. Pernice, V. Fogliano and G. Barbieri (2007). Sulphur fertilization may improve the nutritional value of Brassica rapa $\mathrm{L}$. subsp. sylvestris. Europ. J. Agron, 26: 418-424.

De Nicola, G.R., I. Blazevic, S. Montaut, P. Rollin, J. Mastelic, R. Iori and A. Tatibouet (2011). Glucosinolate distribution in aerial parts of Degenia velebitica. Chem. Biodivers, 11: 20902096.

Dolezalova, I., M. Duchoslaw and K. Dusek (2013). Biology and Yeild of Rocket (Eruca sativa Mill) under conditions of the Czech Republic (Central Erope). Not Bot Horti Agrobo, 41: 530-537.

Ding, J.L., X. Jiang, M.C. Ma, B.K. Zhou, D.W. Guan, B.S. Zhao, J. Zhou, F.M. Cao, L. Li and J. Li (2016). Effect of 35 years inorganic fertilizer and manure amendment on structure of bacterial and archaeal communities in black soil of northeast China. Appl. Soil Ecol, 105: 187-195.

Fan, F.L., Z.J. Li, S.A. Wakelin, W.T. Yu and Y.C. Liang (2012). Mineral fertilizer alters cellulolytic community structure and suppresses soil cellobio-hydrolase activity in a long-term fertilization experiment. Soil Biol. Biochem, 55: 70-77.

Henalt, Esiyok, D., M.K. Bozokalfa, S. Kavak and A. Ugur (2013). Seed yield,quality and plant characterstics of (Eruca sativa mill) under different nitrogen sources and vegetation periods. J. Faculty of Agriulture, 8: 53-59.

Iheanacho, K.M.E. and A.C. Udebuani (2009). Nutritional composition of some leafy vegetables consumed in Imo State, Nigeria. J. Appl. Sci. Environ. Manag, 13, 35-38.

Januškevičius, A., G. Januškevičienè and V. Andrulevičiūte (2012). Chemical composition and energetic values of selected vegetable species in Lithuanian supermarkets. Vet. Med. Zoot, 58: 8-12.

Koukounaras, A., A.S. Siomos and E. Sfakiotakis (2007). Postharvest $\mathrm{CO} 2$ and ethylene production and quality of rocket (Eruca sativa Mill.) leaves effected by leaf age and storage. Postharvest biology and technology, 46: 167-173

Kamga, R.T., C. Kouame, A.R. Atangana, T. Chagomoka and R. Ndango (2013). Nutritional evaluation of five African indigenous vegetables. J. Hort. Res, 21: 99-106. 
Kim, S.-J. and G. Ishii (2006). Glucosinolate profiles in the seeds, leaves and roots of rocket salad (Eruca sativa Mill.) and anti-oxidative activities of intact plant powder and purified 4methoxyglucobrassicin. Soil Sci. Plant Nutr, 52: 394-400.

Kanchan, L.V. and D. Veenapani (2011) Nutritional analysis of indigenous wild edible herbs used in eastern Chhattisgarh, India. Emir. J. Food. Agric, 23: 554-560.

Liu, B.; Gumpertz, M.L., S. Hu and J.B. Ristaino (2007). Long-term effects of organic and synthetic soil fertility amendments on soil microbial communities and the development of southern blight. Soil Biol. Biochem, 39: 2302-2316.

Lindsay, W.L. and W.A. Norvell (1978). Development of a DTPA Soil Test for Zinc, Iron, Manganese, and Copper. Soil Sci. Soc. Am. J, 42: 421-428.

Lee, J. (2010). Effect of application methods of organic fertilizer on growth, soil chemical properties and microbial densities in organic bulb onion production. Scientia Horticulturae, 124(3): 299305.

Lintas, C. (1992). Nutritional aspects of fruits and vegetable consumption. Options Meditérran, 19: 79-87.

Lim, P.O., H.J. Kim and H.G. Nam (2007). Leaf Senescence. Annual Review of Plant Biology, 58: 115-136.

Løkke, M.M., H. Fast Seefeldt and M. Edelenbos (2012). Freshness and sensory quality of packaged wild rocket. Postharvest Biology and Technology, 73: 99-106.

Malhi, S.S., M. Nyborg, T. Goddard and D. Puurveen (2011). Long-term tillage, straw management and $\mathrm{N}$ fertilization effects on quantity and quality of organic $\mathrm{C}$ and $\mathrm{N}$ in a Black Chernozem soil. Nutr. Cycl. Agroecosyst, 90: 227-241.

Morishita, M., K. Sugiyama, T. Saito and Y. Sakata (2002). An improved evaluation method for screening and selecting powdery mildew resistant cultivars and lines of cucumber (Cucumis sativus L.). J. Japan Soc. Hort. Sci, 71: 94-100.

Malhi, S.S. and K.S. Gill (2002). Effectiveness of sulphate-S fertilization at different growth stages for yield, seed quality and $\mathrm{S}$ uptake of canola. Can. J. Plant Sci, 82: 665-674.

Mitić, V., V.S. Jovanović, M. Dimitrijević, J. Cvetković, G. Petrović and G. Stojanović (2013). Chemometric analysis of chlorophyll a, b and carotenoid content in green leafy vegetables. Biol. Nyss, 4: 49-55.

Nurzyńska-Wierdak, R. (2015). Protein nutritional value of rocket leaves and possibilities of its modification during plant growth. Turk. J. Agric. For, 39: 1023-1028.

Ng, X.N., F.Y. Chye and A. Mohd Ismail (2012). Nutritional profile and antioxidative properties of selected tropical wild vegetables. Internat. Food Res. J, 19: 1487-1496.

Nurzyńska-Wierdak, R. (2009). Growth and yield of garden rocket (Eruca sativa Mill.) affected by nitrogen and potassium fertilization. Acta Sci. Pol. Hortorum Cultus, 8: 23-33.

Oyewole, C.I., H. Opaluwa and R. Omale (2012). Response of Tomato (Lycopersicon esculentum): Growth and yield, to rates of mineral and poultry manure application in the guinea savanna agro-ecological zone in Nigeria. J. Biol. Agric. Health Care, 2: 44-56.

Ould Ahmed B.A., M. Inoue and S. Moritani (2010). Effect of saline water irrigation and manure application on the available water content, soil salinity, and growth of wheat. Agricultural Water Management, 97: 165-170.

Olsen, S.R., C.V. Cole, F.S. Watanabe and L.A. Dean (1954). Estimation of Available Phosphorus in Soils by Extraction with Sodium Bicarbonate; United States Department of Agriculture: Washington, DC, USA.

Omirou, M., C. Papastefanou, D. Katsarou, I. Papastylianou, H.C. Passam, C. Ehaliotis and K.K. Papadopoulou (2012). Relationships between nitrogen, dry matter accumulation and glucosinolates in Eruca sativa Mills. The applicability of the critical N-NO3 levels approach. Plant Soil, 354: 347-358.

Onwordi, C.T., A.M. Ogungbade and A.D. Wusu (2009). The proximate and mineral composition of three leafy vegetables commonly consumed in Lagos, Nigeria. Afr. J. Pure Appl. Chem, 3: 102-107.

Padulosi, S., T. Hodgkin, J.T. Williams and N Haq (2002). Underutilized crops: trends, challenges and opportunities in the 21 st century. Managing plant genetically diversity, Engels, J.M.M.; Ramanatha, R.V.; Brown, A.H.D.; Jackson, M.T. Kuala Lumpur, Malaysia, ISBN 0851995225

Page, A.L., R.H. Millar and D.R. Keeney (1992). (Eds.) Methods of Soil Analysis. Part-2; American Society of Agronomy and Soil Science Society of America: Madison, WI, USA.

Pearson D. (1976). The Chemical Analysis of Foods. London, Churchill Livingstone, 575p.

Patricia, O., L. Zoue, R.M. Megnanou, R. Doue and S. Niamke (2014). Proximate composition and nutritive value of leafy vegetables consumed in Northern Côte d'Ivoire. Eur. Sci. J, 10: 212-227.

Solaiman, A.R.M. and M.G. Rabbani (2006). Effects of NPKS and cow dung on growth and yield of 
tomato. Bull. Inst. Trop. Agric. Kyushu Univ, 1: 31-37.

Sreenivasa, M.N., M.N. Nagaraj, S.N.; Bhat and Beejamruth (2010). A source for beneficial bacteria. Karnataka J. Agric. Sci, 17: $72-77$

Singh, V.K., B.S. Dwivedi, R.P. Mishra, A.K. Shukla, J. Timsina, P.L. Upadhyay, K. Shekhawat, K. Majumdar and A.S. Panwar (2019). Yeilds, Soil Health and Farm Profits under a Rice-Wheat System: Long-Term Effects of Fertilizers and Organic Manures Applied Alone and in Combination. Agronomy, 9: 1.

Sato, T., K. Yoseda, O. Abe and T. Shibuno (2008). Male Maturity, Number of Sperm, and Spermatophore Size Relationships in The Coconut Crab Birgus Latro on Hatoma Island, Southern Japan, J. Crustacean Biology, 28(4): 663-668.

Spadafora, N.D., A.L. Amaro, M.J. Pereira, C.T. Muller, M. Pintado and H.J. Rogers (2016). Multi-trait analysis of post-harvest storage in rocket salad (Diplotaxis tenuifolia) links sensorial, volatile and nutrional data, Food Chemistry, 211: 114123.

Mukhtar, T., M. Arif, S. Hussain, T. Tariq K. Mehmood (2011). Effect of different rates of nitrogen and phosphorus fertilizers on growth and yield of maize. J. Agric. Res, 49(3): 333-339.

Thomas, G.W., G.R. Haszler and R.L. Blevins (1996). The effects of organic matter and tillage on maximum compactibility of soils using the Proctor test. Soil Sci, 161: 502-508.
Toivonen, P.M.A. and D.A. Brummell (2008) Biochemical bases of appearance and texture changes in fresh-cut fruit and vegetables. Postharvest Biology and Technology, 48: 1-14.

Vivek, P., S. Prabhakaran and S.R. Shankar (2013). Assessment of nutritional value in selected edible greens based on the chlorophyll content in leaves. Res. Plant Biol, 3: 45-49.

Walkley, A. and C.A. Black (1934). An examination of the Degitjareff method for determining soil organic matter, and a proposed modification of the chromic acid titration method. Soil Sci, 37: 29-38.

Wierdak, R.N. (2009). Growth and yield of garden rocket (Eruca sativa Mill.) affected by nitrogen and potassium fertilization. Acta Sci. Pol., Hortorum Cultus, 8: 23-33.

Yadav, S.S., M.L. Jakhar and L.R. Yadav (2013). Response of taramira (Eruca sativa) to varying levels of FYM and vermicompost under rainfed conditons. J. Oilseed Brassica, 4: 49-52.

Yao, H., Z. He, M.J. Wilson and C.D. Campbell (2000). Microbial biomass and community structure in a sequence of soils with increasing fertility and changing land use. Microb. Ecol, 40: 223-237.

Zhao, S.C., K.J. Li, W. Zhou, S.J. Qiu, S.W. Huang and P. He (2016). Changes in soil microbial community, enzyme activities and organic matter fractions under long-term straw return in north-central China. Agric. Eco-syst. Environ, 216: 82-88. 